\title{
What do we know about individual equity options?
}

\author{
Alejandro Bernales
}

Nikolaos Voukelatos
Thanos Verousis

Mengyu Zhang*

This version: August 10th, 2019.

\begin{abstract}
This paper examines the empirical literature on individual equity options, discussing results in areas of consensus, showing findings in areas of disagreement and providing a guide for future research (especially highlighting analyses that cannot be performed with index options). Key topics include the impact of equity option listings on the underlying stock market, option market efficiency, anomalies in equity option returns, option market microstructure, investors' behavioural biases, option price discovery and private information revealed in equity option markets. Some directions for future research include the determinants of equity option returns and the effect of algorithmic trading in option markets.
\end{abstract}

Keywords: Equity options, empirical studies, literature survey.

JEL Codes: G12, G13, G14, G41.

\footnotetext{
*Alejandro Bernales is at Universidad de Chile (Centro de Economía Aplicada and Centro de Finanzas, DII), e-mail: abernales@dii.uchile.cl. Thanos Verousis is at University of Essex (Essex Business School), email: T.Verousis@essex.ac.uk. Nikolaos Voukelatos is at Kent Business School, University of Kent, e-mail: N.Voukelatos@kent.ac.uk. Mengyu Zhang is at University of Essex (Essex Business School), e-mail: M.Z18893@essex.ac.uk. Alejandro Bernales acknowledges financial support from Fondecyt project \#1190162 and the Institute for Research in Market Imperfections and Public Policy (ICM IS130002, Ministerio de Economía de Chile). Any errors made are our own.
} 


\title{
What do we know about individual equity options?
}

This version: August 10th, 2019.

\begin{abstract}
This paper examines the empirical literature on individual equity options, discussing results in areas of consensus, showing findings in areas of disagreement and providing a guide for future research (especially highlighting analyses that cannot be performed with index options). Key topics include the impact of equity option listings on the underlying stock market, option market efficiency, anomalies in equity option returns, option market microstructure, investors' behavioural biases, option price discovery and private information revealed in equity option markets. Some directions for future research include the determinants of equity option returns and the effect of algorithmic trading in option markets.
\end{abstract}

Keywords: Equity options, empirical studies, literature survey. JEL Codes: G12, G13, G14, G41. 
What is the current knowledge regarding individual equity options? In spite of the rapid growth of equity option markets since the first day of trading on the Chicago Board Option Exchange (CBOE) on April 26, 1973, there has been no effort in the financial economics literature to consolidate, in a literature review, the current knowledge and understanding of individual equity options. The number of empirical papers examining individual equity options has increased at a slower rate than the number examining index options. This is mainly due to problems with data availability and relatively low trading activity observed in individual equity option markets, compared with index options that have historically been highly traded. However, data availability and trading activity on individual equity options have increased in the last decades, such that the volume of empirical papers on individual equity options has now reached a level that merits a survey of this literature.

The objective of this study is to offer a systematic review of the empirical literature on individual equity options, by discussing questions examined, data sets used and main findings, and providing some avenues for future research. Our survey of the equity options literature shows several research areas that have emerged, ranging from topics of relative consensus and solid understanding, to areas where the evidence is rather mixed and more research is required.

Although a chronological literature review could highlight the historical changes in the research field, studies on equity options span several research topics, which could make a chronological review needlessly complicated. Thus, studies in this survey are primarily ordered thematically, to provide a big picture of the knowledge on individual equity options. We mainly focus our attention on empirical studies where individual equity option data are used. Thus, in this literature review, we do not consider theoretical studies, which can be applied to options with other underlying types, such as indexes, bonds or exchange rates. However, in some parts of this empirical literature review, we will briefly mention theoretical advances that apply to 
options, as a means to better understand the results obtained in the empirical studies on individual equity options.

Before starting our literature review on individual equity options, it is important to answer the following question: What can we learn from empirical studies on individual equity options that we cannot learn from empirical studies on index options? This is an important question, since its answer makes the current survey valuable and provides a motivation for its development. There are many reasons why it is useful to analyse individual equity options rather than index options. Firstly, there are analyses that can be performed more cleanly with individual equity options than with index options. For example, the analysis of the factors that affect the introduction and success (in terms of trading activity) of new options listed for the very first time is difficult to perform with index options. This is because there are not many listings of index options in option market history, while there are plenty of listings of individual equity options (e.g., Mayhew and Mihov, 2004; Danielsen et al., 2007; and Bernales, 2017). For instance, on the first day of option trading on the CBOE in 1973, individual equity options were traded on 16 stocks, and no option contracts were traded on indexes (the first index option was introduced only 10 years later in 1983). The large number of listings of individual equity options in the following years, compared with listings of index options, can be observed in the current option market status. For example, in 2018, individual equity options were traded on 4,337 stocks, while index options were traded on only 34 indexes in the United States. ${ }^{2}$ Moreover, the large number of equity options is not only useful for studies on option listings, but also allows researchers to perform robust cross-sectional analyses of the impact of option listings on the underlying assets, by controlling for specific features of the option contracts and stocks (e.g. trading activity, market volatility, firm industry, amongst others).

Secondly, in addition to topics that are difficult to examine using index options due to the very low frequency at which certain events are observed (such as option listings as discussed above), there are other research questions where equity options can provide a more

\footnotetext{
${ }^{2}$ Information obtained from the Option Clearing Corporation web page, www.optionsclearing.com.
} 
fertile ground for analysis, due to the specific type of information that is relevant to their trading. This is the case with some studies that examine potential information flows between the option market and the underlying asset market (e.g. Stephan and Whaley, 1990; Chan et al. 2002; Muravyev et al., 2013). For instance, we will describe studies that show that levels of informed trading in the underlying stock market are reduced after the introduction of equity options, which can improve the price discovery process (i.e. the process by which information is progressively incorporated into prices). In fact, we can expect informed agents to use their private information for trades in stocks in which they have informational advantages, which is captured in the trading activity of stocks by market microstructure models (e.g. Easley et al., 1996, 1997, 1998a; Odders-White and Ready, 2008; and Duarte and Young, 2009). The private information that agents may have on indexes is not the same in nature as the private information on a particular stock, which makes the analysis of information flows between the option market and the underlying asset market different. In particular, private information on a particular stock is mainly related to undisclosed news or events regarding the firm that issued the stock, while private information on indexes mainly reflects some anticipated global economic view of the market.

Thirdly, individual equity options and index options are dissimilar in the sense that they attract different types of investors, and thus demand for them reacts to different factors. For instance, Lemmon and $\mathrm{Ni}$ (2014) show that equity options (index options) are actively traded by individual investors (sophisticated institutional investors). Lemmon and Ni (2014) also present evidence that trading activity in equity options is related to individual investors' sentiment and past market returns, while trades of index options are motivated by a hedging demand. Along similar lines, Johnson et al. (2016) show that index options are mainly used for hedging purposes in relation to crash risks for the whole market. As a result, findings from the literature on index options in terms of agents' behaviours cannot necessarily be extended to the case of individual equity options. 
For all the reasons described above, a systematic review of the current state of the literature on individual equity options (which is independent of the index option literature) is both timely and particularly important. We start this literature review in Section 2 by discussing the relationship between the equity option market and the underlying stock market. Under the Black and Scholes (1973) assumptions, options written on individual stocks represent redundant securities. For instance, the Black and Scholes (1973) option pricing framework is based on the property that the payoff of an option contract can be replicated by a portfolio consisting of the underlying stock and a risk-free bond. Thus, we should expect that the listing of equity options will not affect the underlying stock market. However, in Section 2, we discuss a number of studies which provide evidence that the introduction of individual equity options (i.e. when they are listed for the very first time on the option exchange) does have an impact on the underlying equity securities.

The reported effect of equity option listing on the underlying stock market is a natural starting point for this literature review, since it also suggests that the efficiency of the equity option market may be rejected, which is the second topic of our survey. Thus, we continue the literature review in Section 3 with studies concerned with analysing the efficiency of the equity option market. Here, we discuss papers providing evidence that the market efficiency hypothesis is rejected when equity option data are used. For instance, there is evidence of 'permanent' option mispricing and abnormal returns on individual equity options.

Nevertheless, as argued by Fama (1970), any test of market efficiency is based on a model that specifies the nature of the market, in which prices should fully reflect all available information. Thus, any test of market efficiency is a joint test of efficiency and a particular pricing model. This means that some tests may reject the market efficiency hypothesis because the model behind the test is not well specified. One way for asset pricing models not to be well specified is if they do not incorporate market frictions coming from trading mechanisms in the option markets and/or investors' behavioural biases. This is particularly important because frictions from trading mechanisms and behavioural biases violate the fundamental assumptions 
of the efficient market hypothesis, in relation to there being no market frictions and investors being rational. Thus, we firstly discuss in Section 4 papers related to the effect of trading mechanisms on equity options. In particular, in this section, we examine studies related to the impact of market microstructure on the equity option market, including liquidity determinants, the market-making process, and changes in tick size, amongst other things. Afterwards, at the end of Section 4, we discuss studies that analyse trading behaviours of investors who depart from the rational-investor paradigm.

An alternative argument for why option markets are not efficient, other than the models potentially not being well specified, is that option markets may not be efficient under a strong form, but may be so under a semi-strong form. A market is semi-strong efficient when the current price only reflects information contained in past prices and all public knowledge (e.g. financial statements and news reports). Thus, a semi-strong form of efficiency recognizes that there are agents with private information that is not yet reflected in prices. Therefore, in Section 5, we discuss papers that analyse where informed investors trade (i.e. in the equity option market and/or in the underlying stock market), and the information flows between equity options and their underlying stock, which can help the price discovery process.

Afterwards, in Section 6, we discuss the type of private information revealed by informed investors through equity option prices (i.e. option-implied information). In this section, we describe studies that suggest some option-implied features of the equity option market that forecast underlying stock prices and returns. We also present papers about the option-implied information contained in option prices, regarding the future underlying stock volatility, and discuss studies suggesting that option-implied information can be extracted from equity options, in relation to the credit quality of the companies issuing the underlying stock.

Therefore, our overall objective is to provide a useful framework for understanding the current, wide scope of the empirical literature on equity options. Finally, Section 7 concludes and discusses potential directions for future research. 
This section discusses the empirical literature on the impact option listing has on the underlying stock market, with Table 1 describing the related studies. We split the literature into three groups. In Section 2.1 (see Table 1 Panel A), we discuss empirical studies on the determinants of the introduction of new equity options into the market, and the ex-post success of such equity option listings. Afterwards, in Section 2.2 (see Table 1 Panel B) and Section 2.3 (see Table 1 Panel C), we analyse empirical studies that report short-term and long-term effects, respectively, of equity option listing, on the underlying stock market.

[Insert Table 1 here]

\section{$2.1 \quad$ The option-listing decision}

We begin the literature review by discussing papers related to the listing process for equity options (Table 1 Panel A). The listing process for equity options is very different to that of the Initial Public Offerings (IPOs) that take place in the underlying stock market, with the decision to conduct IPOs being taken by the company that issues the stocks, while the optionlisting decision is taken directly by the option exchange. The option-listing process is examined by Mayhew and Mihov (2004) and Danielsen et al. (2007). In particular, they report that stock volatility and stock liquidity are the most important ex-ante (before the listing date) selection factors used by option exchanges to choose a stock to be used as the underlying asset for an option listing. This is expected, since equity options are more attractive when the volatility increases, given that investors may use options either to reduce their volatility exposure or to exploit changes in the levels of volatility by using option portfolios such as straddles. In addition, stocks with high liquidity are more likely to have the attention of more market participants, who will also be willing to trade options with such stocks as the underlying.

Additionally, for each new option contract there is no initial established number of contracts that have to be traded. This again differs from IPOs, where the number of assets is 
exogenously determined by the issuer. Conversely, the number of option contracts is established through an endogenous process, based on the willingness of investors to participate in and trade the newly listed securities. Thus, a new call option contract is created (with a given moneyness and time-to-maturity, and with stock $S$ as the underlying) when an investor wants to sell this contract and another investor is simultaneously willing to buy the same contract. In this sense, we can judge the success or failure of a new option's introduction based on the number of option contracts. For instance, Bernales (2017) examines factors that predict the $e x$ post success of stock option introductions, and shows that measures of information asymmetries predict option adoption rates. Informed traders will want stocks about which they have access to superior information to be optioned. This is because options offer cheap ways to effectively turn private information into profits, due to the leverage inherent in option contracts. Thus, the trading activity of informed investors, especially when an equity option has only recently been listed, may trigger the whole ex-post demand for the new option.

\subsection{Short-term impact of option introductions on the equity market}

After new equity options have been listed, it is interesting to analyse their impact on the underlying stocks (Table 1 Panel B). The empirical evidence on the impact of option listing on the underlying stock market is mixed. In one of the earliest studies on this topic, Detemple and Jorion (1990) examine individual equity options in the US market during 1973-1986, and document significantly positive stock returns during a two-week window surrounding option introduction. They also show that option introduction resulted in a temporarily lower stock volatility over this period. However, the impact of individual stock option listings on the underlying stock market seems to have disappeared in the later part of their sample period. Gjerde and Saettem (1995) and Watt et al. (1992) argue that this positive impact might be driven by liquidity suppliers charging a premium for their services, and by the hedging-related demands of dealers. Bollen (1998), Hamill et al. (2002), Gjerde and Saettem (1995), and Watt et 
al. (1992) further confirm the positive impact of option listing on the underlying stock prices, an effect that nevertheless gradually disappeared during the post-1980 period.

Freund et al. (1994) examine a similar sample and confirm the results of Detemple and Jorion (1990) in terms of lower stock volatility following option listing during the earlier part of the sample period. However, Freund et al. (1994) find that the introduction of individual stock put options has a negative effect on the underlying stock prices, a finding consistent with the hypothesis that put options allow investors to trade on negative information more efficiently than when they can only trade in stocks. Another potential explanation for the negative effect of option introduction on the underlying stock is related to the short-sale constraints that some financial institutions face. When there is no option market for a stock, traders with additional, negative information about the stock cannot take bearish positions if the costs of short-selling are too high. However, after the introduction of options on such a stock, the negative views of traders can be exploited, since short positions can be generated by buying puts or writing calls. Danielsen and Sorescu (2001) present evidence that the negative impact of the introduction of equity options on the underlying stock prices is consistent with the mitigation of short-sale constraints.

\subsection{Long-term impact of option introduction on the equity market}

Panel $\mathrm{C}$ of Table 1 shows the main empirical findings on the longer-term impacts of equity option introduction. We can observe from this table that there is a variety of long-term potential effects of new equity option listing on the underlying stock market, and a lack of consensus about the nature of such relationships.

Conrad (1989) is the first study to show that introducing option contracts causes a permanent price increase in the underlying stock, as evidenced by significantly higher stock prices in the long run. This empirical finding is supported by Detemple and Selden (1991), who develop a theoretical framework to link the incomplete primary market to the derivatives 
market, in which the prices of the underlying stocks are expected to change in response to the listing of new derivative contracts. However, Mayhew and Mihov (2000) challenge whether this effect is consistently positive. After correcting for the endogeneity of the decision to list options, Mayhew and Mihov (2000) show that the impact of option listing on stock prices was positive pre-1981 but turned negative post-1981. Furthermore, Ni et al. (2005) show evidence of a negative impact of equity option introductions on the underlying stock market, through a significant tendency for the prices of stocks on which options are written to cluster around strike prices on option expiration dates.

In terms of the long-term effects of option introduction on stock volatility, Skinner (1989) and Damodaran and Lim (1991) find that the volatility of the underlying stock market decreases significantly after the listing of options. Jennings and Starks (1986) argue that this effect is due to option contracts allowing stock prices to absorb new information more efficiently. Conversely, Faff and Hillier (2005) and Liu (2010), focusing on the UK and Japan, respectively, find that stocks on which options are written tend to have higher levels of return volatility than non-optioned control groups. Thus, the empirical findings of Faff and Hillier (2005) and Liu (2010) cast some doubt on the effect option listing has on volatility. Moreover, Mayhew and Mihov (2004) find no evidence that volatility changes with option introduction, using a control-sample methodology designed to correct for the endogeneity of option listing. In addition, Mazouz (2004) suggests that there are changes in market-wide volatility that should be considered in tests of the impact of equity options on the underlying stock market. Using a conditional volatility model, Mazouz (2004) shows that option listing has no significant effect on stock volatility after accounting for the time variation in stock variances.

Option listing has also been found to have a long-term effect on the market performance of the underlying stock market. For instance, Agyei-Ampomah and Mazouz (2011) show that stocks with options written on them co-move more strongly after the decision to list has been made, which induces a reduction in diversification benefits for the underlying optioned stocks. Fedenia and Grammatikos (1992) find that stocks with options written on them have 
significantly higher liquidity. Sahlstrom (2001) examines the Helsinki Stock Exchange and finds that option listing results in tighter bid-ask spreads for the underlying stocks. Kumar et al. (1998) confirm the positive effect of option listing on stock liquidity, while also reporting lower information asymmetry and improved price efficiency for the optioned stocks. Nevertheless, Danielsen et al. (2007) show evidence that equity options do not systematically improve the market liquidity of the underlying security; rather, the market liquidity of the underlying security improves before the listing decision is made. Furthermore, Bernales (2017) confirms the results of Kumar et al. (1998) in terms of a reduction in asymmetric information after option listing. He shows that successful listings end up improving market quality in terms of a reduction in the levels of asymmetric information observed in the underlying stock market.

In summary, whilst the decision to introduce options on the underlying stocks is a function of stock volatility and stock liquidity, the success of equity option introductions is also related to information asymmetries. Moreover, a consensus has emerged on the positive effect of option introductions on stock returns and in terms of reductions in asymmetric information; however, the literature is clearly not conclusive on the impact of these introductions on stock volatility and stock liquidity.

In relation to similar studies on index options, as with the effect of equity option introductions on underlying stocks, the literature on index options also shows mixed results. For instance, Rahman (2001) shows that the introduction of derivatives trading on the Dow Jones Industrial Average (DJIA) index futures and futures option contracts is not associated with any changes in the volatility of the underlying stock components of the DJIA index. Harris (1989) shows that, since the start of trading in index options, stock components of the S\&P 500 index have been relatively more volatile, with a difference that is statistically (but not economically) significant. Furthermore, Kumar et al. (1995) show that trading volume, volatility, and bid-ask spreads decline for the stocks contained in the Nikkei 225 index after the listing of the index options. 
Is the individual equity option market efficient? In this section, we discuss the papers that attempt to answer that question. As we explained in the introduction, under the Black and Scholes (1973) assumptions, individual equity options are redundant securities (i.e. they can be replicated by a portfolio consisting of the underlying stock and a risk-free bond). However, as we highlighted in the previous section, there are studies showing some evidence that the introduction of equity options has an impact on the underlying stock market, which suggests that the efficiency of the equity option market may be rejected. Hence, in this section, we present the studies that explicitly test the hypothesis of market efficiency among individual equity options. The studies discussed in this section are presented in Table 2.

[Insert Table 2 here]

We start, in Section 3.1 (see Table 2 Panel A), by discussing option mispricing in the individual equity option market, reporting on studies providing evidence that 'permanent' arbitrage opportunities exist. If the option market were efficient, investors should detect and trade options that were mispriced, which should move option prices to their 'correct' values and potential option mispricing should disappear. However, in this section, we discuss studies reporting evidence of 'permanent' option mispricing, which suggests that the equity option market may not be efficient. Furthermore, in Section 3.2 (see Table 2 Panel B), we examine studies reporting anomalies in the returns of equity options.

\subsection{Option mispricing}

To commence our survey on option mispricing in individual equity options, in an early study, Galai (1978) shows that, in contrast to theoretical predictions, closing prices of stocks and options do not satisfy no-arbitrage conditions. Galai (1978) then develops a trading strategy that exploits mispricing opportunities, resulting in profits that are on average positive, albeit relatively small when compared to their variability. In a similar vein, Castagna and Matolcsy 
(1982) develop a two-stage approach for testing market efficiency, based on the returns offered by strategies that exploit potential option mispricing. Using Black and Scholes (1973) implied volatilities to detect potential mispricing, Castagna and Matolcsy (1982) find that a portfolio that is long in underpriced options and short in overpriced ones offers abnormal positive profits. However, these profits are eliminated when transaction costs are taken into account. In addition, Norden (2001) shows that equity option prices do not move as expected after stock price changes. For instance, the prices of calls and puts may move in the wrong direction compared to what the movement of the underlying stock would suggest, or the price changes in different option contracts written on the same stock may be uncorrelated with one another.

Additionally, Battalio and Schultz $(2006,2011)$ test for option mispricing during periods of short-sale constraints, since traders can generate synthetic short-sale positions by buying puts or writing calls. Using a sample of options written on US stocks during the peak of the internet bubble in 2000, when short-selling restrictions had been put in place, Battalio and Schultz (2006) find no evidence of tradeable arbitrage opportunities in the option market. However, in a later study, Battalio and Schultz (2011) show that the 2008 short-sale restrictions resulted in a significant dislocation between actual and synthetic prices of banned stocks. More specifically, Battalio and Schultz (2011) find that option-based synthetic prices of banned stocks were significantly lower than the actual prices, suggesting that market makers had increased the ask prices for puts, and lowered the bid prices for calls, potentially because the short-sale ban had substantially reduced their ability to hedge their inventory. As a result, trading in the option market became much more costly for investors, with Battalio and Schultz (2011) suggesting there was a $\$ 500$ million extra liquidity cost during that period.

\subsection{Abnormal returns on individual equity options}

This section surveys the literature on the abnormal returns observed on individual equity options. In an early study, Sheikh and Ronn (1994) examine the intraday patterns of 
individual stock option returns in the $\mathrm{CBOE}$ and their relationship to trading patterns in the underlying stocks. For instance, they find that option returns are, on average, negative between 9:00 and 10:00, while on Tuesdays and Thursdays option returns are significantly positive. Moreover, there are some differences between the patterns in the returns on call versus put options (e.g. put option returns are positive on Fridays and negative over the weekend, but this is not observed in call option returns). This suggests that informed and discretionary liquidity traders do exhibit strategic trading behaviour in the option market.

Years later, although Coval and Shumway (2001) find that theoretical properties of option returns are confirmed in the historical returns of S\&P 500 index options under mild assumptions (i.e. expected call returns exceed those of the underlying security and increase with the strike price), Ni (2008) shows that this is not the case for individual equity options. Examining the returns of options written on the constituent stocks of the S\&P 500 from 1996 to 2005, Ni (2008) finds that the returns of out-of-the-money calls are on average negative. In addition, Ni (2008) finds that call options with high strike prices tend to offer lower returns, on average, than call options with low strike prices.

There is also evidence of a relationship between individual equity option returns and the volatility risk premium (VRP), i.e. the difference between implied volatility and realized volatility. For instance, Goyal and Saretto (2009) focus on the VRP as an element that affects the cross-section of individual equity option returns. Treating large values of the VRP as indicative of option mispricing, they show that going long in options with the highest values of VRP and short in options with the lowest values of VRP generates statistically and economically significant returns. Importantly, the profitability of this trading strategy cannot be explained by a set of common risk factors or idiosyncratic characteristics, and it remains significant even after accounting for transaction costs and margin requirements. However, recently, Bernales et al. (2017) have offered a theoretical explanation for the relationship between the VRP and option returns. They use learning to explain both why implied volatility deviates from historical 
volatility and how this deviation generates predictive dynamics in the returns of option portfolios due to the recursive process induced by learning mechanisms.

Cao and Han (2013) find that dealers charge a higher premium for options written on stocks with higher idiosyncratic volatility, due to higher arbitrage costs. As a result, deltahedged option returns are shown to be abnormal and negatively related to the idiosyncratic volatility of the underlying stocks. Vasquez (2017) shows that option returns are positively related to the slope of the implied volatility term structure, and abnormal option returns are observed from strategies based on the implied volatility term structure.

Boyer and Vorkink (2014) focus on the third moment of the returns distribution and report a negative relationship between individual equity option returns and ex-ante skewness. This negative cross-sectional relationship is not subsumed by the option's moneyness, and it results in abnormal returns for option portfolios with high ex-ante skewness. Additionally, Driessen et al. (2009) investigate the effects of market-wide correlation shocks on expected option returns. Increases in correlation at the aggregate market level are expected to have a negative impact on investor welfare through a reduction in diversification benefits and an increase in market volatility. Using data on options written on the S\&P 100 constituent stocks, Driessen et al. (2009) find evidence of a significant correlation risk premium in the crosssection of individual option returns, with trading strategies exploiting priced correlation risk generating abnormal returns.

Overall, the empirical studies above show that there are some market inefficiencies in individual equity options. In particular, market inefficiencies have been documented with regard to 'permanent' option mispricing and abnormal returns on these options. Moreover, we show that our understanding is very limited regarding the determinants of the abnormal returns observed in individual equity options.

In relation to the index option market, and in line with some results for the individual equity option market, Evnine and Rudd (1985), Sim et al. (2016), and Ackert and Tian (2001) 
show that index options often violate the no-arbitrage conditions. Regarding index option returns, Coval and Shumway (2001) show that, while returns on index options follow theoretical properties under mild assumptions, returns on index option portfolios do not respect theoretical features under strong assumptions (i.e., under strong assumptions, expected option returns should vary linearly with option betas). For instance, Coval and Shumway (2001) document strong negative average returns in zero-beta at-the-money straddles using index options, which should not be observed. Bondarenko (2003) looks at simple trading strategies involving naked puts, and shows that they yield large profits for the options' sellers. In a multifactor analysis, Jones (2006) finds high abnormal negative returns to be associated with shortterm out-of-the-money puts. Constantinides et al. (2013) show that a single-factor model fails to explain the cross-section of index option returns. They also report a decreasing trend in the magnitude of leverage-adjusted put index option returns as the moneyness and time-tomaturity rise.

However, some potential explanations for the abnormal behaviour of index options have appeared in the last years. For instance, Broadie et al. (2009) show that index option returns can be explained by models that can generate jump risk premiums or an estimation risk (i.e., when agents cannot estimate parameters and state variables obtained from short samples). Broadie et al. (2009), though, do not provide an economic justification for the existence of such models. However, recently, Bernales et al. (2019) have shown that one potential economic explanation for the abnormal returns observed in index options may be the learning process followed by investors.

\section{The market microstructure and behavioural biases in individual equity options}

In this section, we focus on the market microstructure properties and behavioural biases of investors observed in the case of individual equity options, which may explain the results seemingly showing that the equity option market is not efficient (see Section 2). 
Importantly, the fundamental assumptions of the efficient market hypothesis, in relation to no market frictions and investor rationality, do not hold when considering market microstructure properties and behavioural biases. Therefore, given that tests of market efficiency depend on the option pricing model (and its assumptions) used to describe the market, then some option pricing models might not be well specified, in the sense of not considering market frictions related to trading mechanisms, and/or investors' irrational behaviours. With this in mind, in this section we survey the literature on the effect of market microstructure on equity options, and then trading behaviours of investors that depart from the rational-investor paradigm. Table 3 presents the empirical studies that have examined these topics.

[Insert Table 3 here]

As a first step, in Section 4.1, we focus on the empirical studies that investigate the liquidity of equity option contracts (see Table 3 Panel A). This section starts with a review of the empirical studies that investigate option liquidity patterns. Afterwards, we discuss the studies that investigate the determinants of option liquidity. In Section 4.2, we discuss studies that investigate the impact of market microstructure changes on option liquidity (see Table 3 Panel B). Finally, in Section 4.3 (see Table 3 Panel C), we discuss some studies that analyse potentially irrational behaviours of agents, which may also explain why the equity option market is inefficient.

\subsection{Option liquidity patterns and determinants}

In Table 3 Panel $\mathrm{A}$, we present the empirical studies that discuss intraday patterns in individual equity option liquidity. In the earlier literature, Aggarwal and Gruca (1993) and Chan et al. (1995) find evidence that the bid-ask spreads of equity options follow an L-shaped pattern during the trading day (i.e. a pattern in which bid-ask spreads decline sharply after trading opens, and then level off), which is different from the U-shaped pattern observed in the underlying stock market. Aggarwal and Gruca (1993) and Chan et al. (1995) suggest that 
potential explanations for this L-shaped pattern are related to the competition in market making, and the informed trading observed in equity option markets, which cause an increase in activity at the beginning of the day. Segara and Sagara (2007) further confirm this finding for the Australian Options Exchange.

A number of studies have also explored the determinants of liquidity across different equity option markets. A large part of this literature focuses on the effect of market microstructure on option liquidity. For instance, in one of the earliest studies in this research area, Vijh (1990) compares the liquidity of options listed on the CBOE to the liquidity of the underlying stocks that are traded on the New York Stock Exchange (NYSE). Vijh (1990) shows that options and stocks have comparable bid-ask spreads. However, due to having multiple dealers per contract, options exhibit a significantly greater market depth than the underlying stocks, suggesting they are more efficient at absorbing larger trades.

Berkman (1993) also analyses the role of market microstructure characteristics in option liquidity by examining the hybrid market of the Options Exchange in Amsterdam, which is characterized by the existence of market makers and a limit order book. Berkman (1993) highlights the importance of limit orders for option liquidity, in the sense that limit orders supply liquidity more cheaply than market makers. Maberly et al. (2010) and Ap Gwilym and Verousis (2013) analyse the levels of liquidity for different contracts (i.e. with different degrees of moneyness and times-to-maturity) written on the same underlying asset. They find clustering for particular strike prices and times-to-maturity.

A related part of the literature attempts to explain the bid-ask spreads observed in options through the prism of hedging costs and asymmetric information, which should increase the spreads. For instance, Lakonishok et al. (2007) and Flint et al. (2014) find that the bid-ask spreads of individual equity options are affected by the cost of hedging the option contracts. Goyenko et al. (2015) examine intraday data on options written on the S\&P 500 constituents, and they also document a significant impact of market makers' hedging costs, with the future 
rebalancing cost dominating the initial hedging cost. Cao and Wei (2010) show evidence that asymmetric information is one of the main components of the bid-ask spread. Verousis et al. (2016) further show that volume and volatility are positively related to the bid-ask spreads of individual equity options, consistent with information asymmetry and hedging-cost effects on option liquidity. Christoffersen et al. (2017) confirm the previous literature by showing that proxies for asymmetric information and hedging costs (and also stock illiquidity, inventory risk, and option order imbalances) are significant drivers of effective spreads.

Wei and Zheng (2010) find evidence that the bid-ask spread is affected by maturitysubstitution and moneyness-substitution in option trading, with these effects driven by expiration cycles and stock return volatility. Examining a large sample of options written on US stocks, Wei and Zheng (2010) show that, due to the structure of the expiration cycles in the option market, demand shifts predictably from medium-term to short-term options when the third expiration month is too far away. Moreover, higher levels of stock return volatility seem to shift demand for options from in-the-money to out-of-the-money contracts. These substitution effects have significant impacts on the bid-ask spreads of different option contracts.

Furthermore, Mayhew et al. (1999) show that the liquidity of individual equity options is significantly related to the underlying stock market. More specifically, Mayhew et al. (1999) find that equity option liquidity is positively related to the price volatility, trading volume, and firm size of the underlying stocks. In addition, this relationship seems to be bi-directional, since stocks with liquid options tend to exhibit higher liquidity themselves. This significant relationship between the liquidity of options and that of the underlying stocks is further supported by the empirical findings of Verousis and ap Gwilym (2013).

\subsection{Impact of market microstructure changes on option liquidity}

Panel B of Table 3 presents the studies that investigate the impact of changes in market microstructure on the liquidity of individual equity options. Neal (1987) examines option 
trading in the US in the late 1980s and finds that the listing of options on multiple exchanges significantly lowers transaction costs. Mayhew (2002) confirms this finding in an extended sample period (1986-1997). However, Battalio et al. (2001) find that option transactions executed in multiple exchanges are usually executed at economically inefficient prices. More specifically, Battalio et al. (2001) show that the introduction of a national market system for equity options in the US has led to an improved quality of execution and lower option spreads.

Pinder (2003) reports that options traded in an order-driven system are characterized by a lower bid-ask spread. Anand and Weaver (2006) investigate option trading on the CBOE and find that the introduction of a designated primary market maker has led to a reduction in the quoted and effective spreads. Anand et al. (2016) further show that the make-take structure could reduce execution costs and, as a result, increase the quote competition among liquidity suppliers. In particular, the introduction of this structure could encourage liquidity suppliers to be more competitive when providing liquidity, and to post better prices that benefit liquiditydemanding traders.

Focusing on the short-selling restrictions that were imposed on a number of US stocks after the financial crisis, Battalio and Schultz (2011) find that the spreads increased significantly for such stocks. This result is further confirmed by Verousis and ap Gwilym (2013) for option trading in Europe. More specifically, Verousis and ap Gwilym (2013) show that equity option liquidity dropped substantially after the short-sale ban of 2008, consistent with the hypothesis that, when market makers cannot hedge their inventories easily, trading costs in the option market increase significantly. Moreover, Verousis et al. (2015) explore the effect of a change in tick size on the liquidity of individual equity option trading, in the NYSE LIFFE. Although introducing a smaller tick size is found to have had a positive effect on option liquidity, as evidenced by smaller spreads, the lower depths observed after the tick size reduction are indicative of a deterioration in the market's ability to absorb larger trades. 


\subsection{Investor behaviours departing from rationality}

The analysis and tests of option market efficiency assume rationality, and thus some results may be affected by non-rational trading behaviours of investors. Therefore, Panel $\mathrm{C}$ of Table 3 presents a number of studies that focus on the behavioural properties of trading in individual equity options. These studies do not explicitly test for the efficiency of option markets, but they examine certain types of behaviour that could potentially deviate from the rational-investor paradigm.

In this context, Poteshman and Serbin (2003) and Hao et al. (2010) investigate the earlyexercise decision in exchange-traded options on individual stocks. They identify a large number of early exercises as irrational, even without using a particular option pricing model. These irrational early exercises of individual equity options appear to be triggered by the underlying stocks reaching their peak level from the previous year and/or by having high stock returns. Poteshman and Serbin (2003) further show that this irrational behaviour is not uniform across all investor types, being exhibited mostly by customers of discount brokers and those of fullservice brokers, rather than by traders from large investment institutions.

Lemmon and Ni (2014) find that demand for individual equity options that increase exposure to the underlying is positively related to individual investor sentiment and past market returns. This finding is not observed in index options, which suggests that there are behavioural biases among individual 'unsophisticated' investors. This is because individual equity options (index options) are actively traded by individual investors (sophisticated institutional investors). Moreover, Lemmon and Ni (2014) find that individual equity options in which a higher proportion of trading is carried out by less sophisticated investors have prices that are more sensitive to the individual sentiment, which is consistent with their behavioural arguments.

In a more recent study, Bernales et al. (2016) find evidence of herding behaviour in the US equity option market, with investors suppressing their own beliefs in favour of the market 
consensus, during periods of market stress. This herding behaviour is reflected in investors being heavily influenced by the contemporaneous returns of index options when they are pricing individual stock options, resulting in a price clustering that reduces the ability to hedge positions efficiently.

In summary, there is a relative consensus about the significant impact of the option market microstructure on equity option markets. There is evidence of an L-shaped pattern of option bid-ask spreads, and empirical studies show that competition in exchanges and liquidity supply improves market efficiency. There is also evidence that option liquidity is related to the price volatility, trading volume, firm size and short-sales constraints of the underlying stock. In addition, option liquidity is negatively affected by hedging costs, inventory costs and adverse selection costs. Furthermore, in terms of behavioural biases, there is some evidence of irrational early exercise in equity options, a relationship between individual investor sentiment and equity option demand, and herding behaviours being exhibited by investors in periods of stress. In fact, understanding investors' behavioural biases in relation to individual equity options could constitute an important field for future research, since very little is known about potentially irrational behaviours of agents in the equity option market.

Regarding index options, ap Gwilym et al. (1997) show that the bid-ask spreads of index options also follow an L-shaped pattern during the trading day, which is consistent with the evidence reported for individual equity options. Moreover, Cho and Engle (1999) and Wu et al. (2014) show that the hedging activities of market makers are the most important determinant of option bid-ask spreads for the index option market. Finally, in relation to potential behavioural biases of agents in the option market, there is little evidence of investor behaviours departing from rationality in the case of index options. This is probably because index options are mainly traded by sophisticated institutional investors, rather than individual investors as is the case with equity options. Probably the paper that comes closest to looking at behavioural biases in index options is that of Diz and Finucane (1993). They present evidence of inefficient 
early exercise of S\&P 100 option contracts, a result that is in line with the findings for equity option contracts.

\section{$5 \quad$ Price discovery}

As described in Section 3, the evidence does not seem to support the market efficiency hypothesis in equity option markets. In Section 4, we discussed that a possible explanation may be related to option pricing models not being well specified, since they do not consider frictions from the market microstructure and/or behavioural biases, which also violate the fundamental assumptions of the efficient market hypothesis. An alternative explanation for potential market inefficiencies is that equity option markets are efficient only in a semi-strong form, in the sense that there are agents with private information that is not yet reflected in option prices. Informed investors with private information might prefer to trade in option markets given the leverage inherent in options, which means they need less capital to exploit their private information than they do in the underlying stock market. Therefore, in this section, we review and discuss the papers that examine the price discovery process (i.e. the process whereby information is gradually incorporated into prices), with Table 4 reporting the related studies.

\section{[Insert Table 4 here]}

In Section 5.1 (Table 4 Panel A), we firstly discuss 'agent-driven' studies, meaning studies examining the impacts of different types of participant (i.e. informed and uninformed agents) on the price discovery process in the equity option market. Afterwards, in Section 5.2 (Table 4 Panel B), we discuss 'event-driven' studies, being studies that analyse the option price discovery process in the light of corporate events or announcements. 


\subsection{Price discovery: Agent-driven studies}

Table 4 Panel A presents the set of studies that investigate the role of agents in the price discovery process. Chakravarty et al. (2004) find that the information share of options in price discovery varies across different underlying stocks, and they suggest that informed investors trade in both the option market and the stock market. Kaul et al. (2004) show evidence that informed investors trade strategically in the equity option market, taking into account the leverage and transaction costs of different option contracts. In addition, Anand and Chakravarty (2007) present evidence of stealth trading in option markets, while Bernales et al. (2018) report liquidity-searching behaviour exhibited by informed investors in option markets as a means to hide their informed-trading strategies.

Conversely, a number of other studies have challenged the hypothesis that informed investors prefer to trade in the option market. Stephan and Whaley (1990) is one of the earliest studies to have argued that the equity market in fact leads the option market in price discovery. Analysing intraday data on firms whose options are traded on the CBOE, Stephan and Whaley (1990) report that the equity market leads the option market by fifteen minutes when the lead/lag relationship is estimated using price changes, with the equity market's lead being even longer when trading volumes are used. Furthermore, Chan et al. (2002) find that net stock trading volume has predictive ability for both stock and option quote revisions, but net option trading volume has no incremental predictive ability. Based on this finding, Chan et al. (2002) argue that informed traders are actually more likely to initiate trades in the stock market than in the option market.

Holowczak et al. (2006) and Muravyev et al. (2013) also support the hypothesis that price discovery is led by the underlying stock market rather than by the option market. They argue that this is due to higher transaction costs in the option market, and the increasing use of automated quoting algorithms by option market makers. O'Connor (1999) provide further evidence of the stock market leading the option market. 


\subsection{Price discovery: Event-driven studies}

Table 4 Panel B presents the studies that investigate the relative contribution of equity options to the price discovery process around corporate events. In this literature, several studies have focused on a particularly important type of corporate news, namely earnings announcements, and examined how the option market incorporates this information into prices. For instance, Patell and Wolfson (1979) provide evidence that option prices reflect the anticipation of a temporary increase in the volatility of the underlying stock due to earnings announcements. This empirical finding is further supported by Levy and Yoder (1993) and Donders et al. (2000).

In addition, Ajinkya and Gift (1985) show that option prices reflect contemporaneous information about the dispersion of analysts' earnings forecasts that is incremental to the information already incorporated in the underlying stock prices. Jennings and Starks (1986) find that the prices of stocks that have options written on them can adjust to earnings announcements more efficiently than the prices of non-optioned stocks. Furthermore, Amin and Lee (1997) show that option traders participate in price discovery around earnings announcements, with individual equity options containing incremental information on top of that contemporaneously available in the underlying equity market. Other empirical studies that report evidence of incremental price discovery in the option market around earnings announcements include Roll et al. (2010), Billings and Jennings (2011), and Atilgan et al. (2015).

Hayunga and Lung (2014) examine the relative contributions of the option and underlying equity markets in terms of price discovery around financial analysts' consensus revisions. Examining individual equity options trading in the US market during 2000-2009, Hayunga and Lung (2014) show that the option market leads the stock market in price discovery when analysts revise their recommendations, and option investors trade in the direction consistent with the upcoming revision approximately three days prior to the announcement. This empirical finding is further confirmed by Lung and Xu (2014), who also 
argue that informed trading in the option market could be driven by information leakage rather than superior stock-picking skills.

Dong and Sinha (2011) examine a broader set of firm-specific news items associated with underlying stocks and find evidence of the option market leading the stock market in price discovery. More specifically, they show that the information share increases much more substantially in the option market than in the equity market around corporate news events, with this difference being even more pronounced after the imposition of short-sale restrictions that followed the 2008 crisis. Moreover, a number of studies document significant changes in the option trading volume around corporate announcement dates. Anthony (1988) and Arnold et al. (2006) find evidence of abnormal trading volumes observed sooner in the option market than in the equity market after corporate announcements are released. In the same vein, Easley et al. (1998a) show that the option trading volumes around announcement dates lead stock price changes over the next few days.

Overall, the debate about whether the option market leads the stock market in price discovery, or vice versa, is far from settled. As described in Section 5.1, the evidence shows that, in normal times, the underlying stock market in general leads the option market in the price discovery process. Nevertheless, when there are corporate announcements, there is evidence that individual equity options are used by traders who are informed about such events, which also contributes to the price discovery process.

In relation to index options, it is important to note that informed investors' private information about indexes is mainly related to an anticipated global economic view of the market, while informed agents' private information about a particular stock is related to undisclosed corporate news. Thus, there are some studies that investigate whether investors who are 'informed' on the index option market can anticipate global market changes, although with mixed results. For instance, Kang and Park (2008) and Hsieh and He (2014) present evidence about information revealed by index options regarding index changes. However, Chen 
and Gau (2009), Chiang and Fong (2001), Schlag and Stoll (2005), and Ryu (2015) present opposing evidence, by showing that index options do not provide substantially more information about the movements of indexes.

\title{
$6 \quad$ Option-implied information in individual equity options
}

In this section, we discuss the type of private information revealed by informed investors in individual equity options. Thus, as a first step, and following on from our discussion in the previous section of studies describing the price discovery contribution made by individual equity options (in which new private information is incorporated and revealed through equity option prices), we examine the type of option-implied information revealed in the equity option market. We divide this section into three types of option-implied information that can be captured from individual equity options: firstly (Section 6.1, Table 5), information about stock prices and returns; secondly (Section 6.2, Table 6), information about stock return volatility; and thirdly (Section 6.3, Table 7), information about probability of default.

\author{
[Insert Table 5 here] \\ [Insert Table 6 here] \\ [Insert Table 7 here]
}

\subsection{Option-implied information about stock prices and returns}

As described above, a number of studies view option prices as measures related to investors' expectations (based on public and 'private' information) about the future prices and returns of the underlying stocks (Table 5). In this research area, Manaster and Rendleman (1982) are among the earliest researchers to have directly compared the option-implied stock price to the actual price of the stock observed in the underlying equity market. They show that option prices contain additional fundamental information not contemporaneously reflected in 
the stock market. This information is reflected in the stock market on average 24 hours later, suggesting that option prices have significant ability to predict future stock prices. Diltz and Kim (1996) confirm the empirical findings of Manaster and Rendleman (1982) regarding the predictive ability of option prices, suggesting that stock prices tend to adjust to the level of option-implied prices over the course of two trading days. Conversely, Bhattacharya (1987) suggests that option prices' ability to predict stock prices is economically insignificant. Although option-implied prices are indeed found to contain information not contemporaneously available in stock prices, Bhattacharya (1987) shows that exploiting this information is not possible when trading costs and other market frictions are considered.

Later studies show that individual equity options' forecasting regarding stock prices and returns can also be derived from higher moments of the risk-neutral distribution. For instance, Govindaraj et al. (2014) and Lin and Lu (2015) find that the volatility of the risk-neutral distribution has significant forecasting power for future stock returns, especially during important firm-specific events. However, Bali and Hovakimian (2009) show that sorting stocks into portfolios based on the volatility of their risk-neutral distribution results in statistically insignificant stock returns; they suggest that it is the call-put risk-neutral volatility spread that is actually predicting future stock returns.

Conrad et al. (2013) use the framework developed by Bakshi and Madan (2000) and Bakshi et al. (2003) to extract the volatility, skewness, and kurtosis of the underlying stock's risk-neutral distribution, and they show that these higher moments can forecast future stock returns. After accounting for risk factors being priced in the cross-section, Conrad et al. (2013) find that the risk-neutral skewness obtained from option prices remains significantly negatively related to future stock returns. Using a different approach to extract risk-neutral skewness from option prices, Rehman and Vilkov (2012) confirm the significant relationship between the skewness of the risk-neutral distribution and future stock returns, but find that this relationship is in fact positive. In a similar spirit, Van Buskirk (2011) finds that the skewness of the riskneutral distribution has significant ability to predict future stock returns, but only in relatively 
short windows around earnings announcements. This ability of the skewness of the risk-neutral distribution to predict future stock returns is further confirmed by Xing et al. (2010), Jin et al. (2012), Liu et al. (2014), and Fu et al. (2016). In a more recent study, Fan et al. (2017) extract forecasts for the return distribution of individual stocks using option prices and high-frequency stock returns. After looking at several combinations, Fan et al. (2017) find that the most accurate forecast of the future return distribution of the underlying stock is obtained by transforming a simple Black and Scholes (1973) risk-neutral density into a real-world density. Importantly, Fan et al. (2017) provide further support for the hypothesis that option-implied information is superior in forecasting future stock returns to the information contained in historical returns.

Another stream of the related literature explores the predictive ability of other implied measures that can be extracted from option prices to predict stock prices and returns. For instance, Cremers and Weinbaum (2010), Liu et al. (2014), and Fu et al. (2016) focus on deviations from put-call parity. They show that such deviations are significantly related to future stock returns, with stocks with relatively expensive calls outperforming those with relatively expensive puts. Furthermore, Jin et al. (2012) show that the forecasting power of deviations from put-call parity is particularly high during important firm-specific information events. Borochin and Yang (2017) argue that the predictive ability of the skewness of the riskneutral distribution and deviations from put-call parity stems from the fact that they reflect anticipated future net leverage changes which, in turn, impact future stock returns.

Han and Zhou (2012) investigate the difference between the risk-neutral implied variance and the realized variance, typically referred to as the volatility risk premium (VRP), as a potential predictor of future stock returns. Using a sample of 500 stocks, they find evidence of the VRP being significantly and positively related to future stock returns. Fu et al. (2016) further show that the ability of the VRP to predict stock returns persists before and after the 2008 crisis. In addition, Bernales and Valenzuela (2016) use the market-aggregate implied correlation to predict stock returns. They show that the implied correlation obtained from options written 
on the constituent stocks of the S\&P 100 index is an indicator of market-wide risk and contains information on future market returns. This predictive ability of implied correlation is particularly strong over quarterly and semi-annual forecasting horizons.

Another part of the related literature examines whether trading volumes in the option market also contain information about the future returns of the underlying stocks. In an early study, Easley et al. (1998b) find evidence against the hypothesis that option trading volumes have unconditional predictive ability over stock returns. However, they also show that the volumes of specific types of option trades, which could be classified as informed trades, are significantly related to future stock returns. Similarly, Cao et al. (2005) also reject the hypothesis of the unconditional predictive ability of option volume, but find that trading-volume imbalances in the option market can forecast stock returns around takeover announcements.

Pan and Poteshman (2006) is the first study to have provided strong evidence on the information contained in option trading volumes about future stock prices. Focusing on new positions opened by investors in the option market, they find that a stock's put-to-call ratio is significantly negatively related to that stock's returns over the next week. Moreover, they suggest that this forecasting power of the put-to-call trading volume ratio stems from informed investors trading on non-public information. Blau and Wade (2013) confirm the significant ability of put-to-call ratios to predict the future returns of individual stocks, but they find that the ratio of short-sales to the total trading volume in the equity market partly subsumes the informational content of the put-to-call ratio. Goyenko et al. (2015) find that option-induced order flows can predict the future returns of the underlying stocks. However, this forecasting power of option trading activity is significant only during periods of decreased option liquidity, when abnormal order flows are more likely to be driven by trading on private information than by liquidity trading.

Roll et al. (2010) introduce the option-to-stock trading volume ratio (O/S) and find that it can be used to forecast future stock returns around earnings announcements. More 
specifically, they find that stocks with higher 0/S levels tend to offer higher returns in the few days after earnings announcements, supporting the hypothesis that a large part of the preannouncement trading in options can be classified as informed. Johnson and So (2012) develop an asymmetric information model to show that, theoretically, the $0 / \mathrm{S}$ ratio and future stock returns are related. They argue that the above relationship is driven by equity short-sale costs, and present a set of empirical results that confirm this theoretical prediction.

\subsection{Option-implied information about the stock return volatility}

As mentioned at the beginning of this section, a growing part of the literature has focused on the forward-looking nature of option contracts regarding the future realized volatility and/or the future option-implied volatility (Table 6). In one of the earliest studies, Latane and Rendleman (1976) use the Black and Scholes (1973) model to extract stock return volatilities implied by option prices. Using a weighted average of implied standard deviations, they find that implied volatility outperforms historical volatility measures in forecasting future realized volatility. Lamoureux and Lastrapes (1993) also show that implied volatility helps to predict future volatility. Mayhew and Stivers (2003) find that the relative predictive ability of implied volatility depends on the option trading volume. More specifically, implied volatility outperforms historically based volatility estimates for stocks with the most actively traded options, but for stocks with lower option trading volumes the information content of implied volatility is subsumed by information contained in the time-series of past returns. The ability of Black and Scholes (1973) implied volatilities to predict individual stocks is further confirmed by Dennis et al. (2006) and Cao et al. (2006).

Taylor et al. (2010) examine whether the model-free approach of Britten-Jones and Neuberger (2000) can produce more accurate volatility forecasts than standard Black and Scholes (1973) implied volatility. When considering short-term forecasting horizons, historical models are generally found to produce more efficient forecasts of future volatility than option- 
implied estimates. However, Taylor et al. (2010) show that implied volatility measures extracted from individual equity options outperform historically based estimates for longer forecasting horizons, with simple at-the-money Black and Scholes (1973) estimates being more informative than model-free implied volatilities. Furthermore, Bernales and Guidolin (2014) focus on forecasting features of the implied volatility surface of equity options. In contrast to Black and Scholes' (1973) assumptions, the volatilities implicit in option contracts written on one underlying asset differ across strike prices and times-to-maturity (which was observed for the very first time by Rubinstein, 1985). This phenomenon is known as the implied-volatility surface (henceforth IVS). Bernales and Guidolin (2014) provide evidence that the IVS for individual equity options can be forecasted using vector autoregressive models, while Bernales and Guidolin (2015) suggest that a potential explanation for the forecasting property derives from the recursive learning process followed by option investors.

\subsection{Option-implied information and the probability of default}

A number of studies have also explored the extent to which option-implied information extracted from individual equity options is associated with the likelihood of a firm's default (Table 7). In this context, Cao et al. (2006) find that the volatility implied by option prices is a significant determinant of credit default swap (CDS) spreads. Analysing more than 1,000 US firms, Cao et al. (2006) show that the informational content of the simple Black and Scholes (1973) at-the-money implied volatility, regarding CDS spreads, is particularly important for firms with lower credit ratings, higher option volumes, and higher option open interest. Benkert (2003) and Da Fonseca and Gottschalk (2014) confirm this strong relationship between optionimplied volatility and credit spreads using international data. Cremers et al. (2008) use options written on individual stocks to extract volatility and jump measures, and they find that both measures are significantly related to a firm's credit spread, which is further confirmed by Kita (2012). In a similar spirit, although from a theoretical perspective, Chen and Kou (2009) 
develop a model of credit risk with two-sided jumps, and show that the resulting implied volatility and credit spreads would be expected to move in the same direction. In addition, Wang et al. (2013) find that the difference between implied and realized volatilities, i.e. the VRP described earlier, has significant explanatory power for credit spreads, especially when implied volatility is measured as the Britten-Jones and Neuberger (2000) model-free expectation.

\section{[Insert Table 7 here]}

Another strand of this literature uses the prices of options written on a firm's stock to explicitly estimate the risk-neutral probability of default. For instance, Capuano (2008) develops a methodology for extracting the risk-neutral probability of default from individual equity options using the principle of minimum cross-entropy, without making any assumptions about the underlying stock's distribution or the recovery rate. Furthermore, Vilsmeier (2016) proposes some technical modifications to the original Capuano (2008) methodology to address issues of accuracy and numerical stability. As an illustrative example, Vilsmeier (2016) uses data on options written on the Bank of America to show that this methodology would have produced implied default probabilities that could have served as an early-warning signal before the bank's downgrading by Moody's in 2011.

Following a different approach, Camara et al. (2012) use a simple lognormal distribution augmented with a probability of default to model stock returns, and they show that the resulting implied probability of default tends to outperform a set of standard credit risk measures. Taylor et al. (2014) propose modelling a stock's risk-neutral distribution as a mixture of two lognormal densities with a default probability. Based on empirical evidence of a closer fit to realized stock return distributions, they suggest that this model allows for a more accurate estimation of the risk-neutral probability of default using prices of individual stock options.

Carr and Wu (2011) develop a theoretical framework that uses the prices of out-of-themoney American put options to compute the value of a synthetic credit insurance contract on the firm's stock. They show that the implied probabilities of default extracted from out-of-the- 
money puts closely match those embedded in CDS spreads. Chang and Orosi (2016) extend their modelling assumption by incorporating a positive expected equity recovery into the framework. They show that this adjustment results in a more accurate estimation of the implied probability of default using options on individual stocks. Conrad et al. (2017) argue that the Carr and Wu (2011) approach requires data on deep out-of-the-money put options, which are not always available for individual stocks. In order to address this limitation, Conrad et al. (2017) propose an alternative framework that uses all available options to infer the implied probability of default, and they find that these option-implied default probabilities are very close to the ones provided by CDS spreads.

In summary, there is consensus on the forecasting features of individual equity options for the prediction of future stock returns, volatility and probability of default. This is due to the forward-looking nature of option-implied information, since options should reflect agents' expectations about future market conditions (i.e. at the time when the option contracts will be exercised). Nevertheless, regarding studies of index options, in contrast to the individual equity option literature that is mostly concerned with firm-specific information contained in equity option contracts, the index option literature focuses on assessing whether option-implied information can be captured about aggregate market conditions. For instance, Faccini et al. (2018) show that option-implied information from index options can be used to predict US real economic activity. Christensen and Prabhala (1998) present evidence that the implied volatility of index options can forecast future aggregate market volatility. Finally, Goncalves and Guidolin (2006) and Bernales and Guidolin (2015) offer evidence that the implied volatility surface from index options, regarding the aggregate market volatility, can be predicted by vector autoregressive models. 


\section{Conclusion and future research}

Over the last few decades, the literature on individual equity options has been growing consistently, in tandem with the increasing trading activity in these derivative contracts in global financial markets. This paper provides a comprehensive review of this literature, highlighting the main empirical findings regarding equity option markets. Our review of the equity option literature identifies several themes that have emerged, ranging from areas of relative consensus and solid understanding, to areas where the evidence is rather mixed and more research is required.

Across the numerous empirical studies on individual equity options, we observe that there is some consensus on the rejection of the classical view of equity options as redundant securities. On this issue, the empirical evidence suggests that introducing options on individual stocks generally has a significant short-term and long-term impact on the underlying equity market, although the precise nature of this impact seems to vary. In addition, empirical studies show that there are market inefficiencies in the equity option market, which are reflected in 'permanent' option mispricing and abnormal option returns. In fact, we seem to understand very little about the determinants of the returns on equity options themselves. Although some idiosyncratic characteristics have been found to be informative in this respect, the literature has yet to develop a credible model for equity option returns.

Furthermore, liquidity in the equity option market seems to depend on market microstructure issues, while equity options are consistently found to contribute substantially to the price discovery process. Nevertheless, the debate about whether the equity option market leads the stock market in price discovery, or vice versa, is far from settled.

Another area of consensus is the forecasting power of option-implied information regarding the future state of the underlying stock market. Given that equity options are forward-looking by design, it is not particularly surprising that a substantial body of empirical 
studies shows that information extracted from equity options has significant ability to predict future stock returns, volatility, and the probability of default.

In terms of potential future research topics, the area of expected equity option returns could constitute an important field for future research. Compared to the vast body of literature on the cross-section of stock returns, our limited understanding of the cross-section of equity option returns seems somewhat surprising. In addition to examining the role of idiosyncratic characteristics, future research could potentially examine the impact of market-wide factors, such as liquidity, short-sale constraints, and market microstructure, on the dynamics of the returns observed on individual equity options.

Besides the lack of clear evidence as to whether the equity option market leads the stock market (or vice versa) in terms of information flows, more research is also needed on the topic of price discovery. A focus on high-frequency data, in particular, could potentially help tackle the question of which market leads the other in this process. Finally, additional research needs to be developed regarding the irrational behaviour of investors regarding equity options, while the area of algorithmic trading in equity options also remains underexplored, and both may provide interesting research topics for future empirical studies.

\section{References}

Ackert, L. F., and Tian, Y. S. (2001). Efficiency in index options markets and trading in stock baskets. Journal of Banking and Finance, 25(9): 1607-1634.

Aggarwal, R., and Gruca, E. (1993). Intraday trading patterns in the equity options markets. Journal of Financial Research, 16(4): 285-297.

Agyei-Ampomah, S., and Mazouz, K. (2011). The comovement of option listed stocks. Journal of Banking \& Finance, 35(8): 2056-2069.

Ajinkya, B. B., and Gift, M. J. (1985). Dispersion of financial analysts' earnings forecasts and the (option model) implied standard deviations of stock returns. The Journal of Finance, 40(5): 1353-1365.

Amin, K. I., and Lee, C. (1997). Option trading, price discovery, and earnings news dissemination. Contemporary Accounting Research, 14(2): 153-192.

Anand, A., and Chakravarty, S. (2007). Stealth trading in options markets. Journal of Financial and Quantitative Analysis, 42(1): 167-187.

Anand, A., and Weaver, D. G. (2006). The value of the specialist: Empirical evidence from the CBOE. Journal of Financial Markets, 9(2): 100-118.

Anand, A., Hua, J., and McCormick, T. (2016). Make-Take Structure and Market Quality: Evidence from the U.S. Options Markets. Management Science, 62(11): 3271-3290.

Anthony, J. H. (1988). The Interrelation of Stock and Options Market Trading-Volume Data. The Journal of Finance, 43(4): 949-964. 
ap Gwilym, O., and Verousis, T. (2013). Price Clustering in Individual Equity Options: Moneyness, Maturity, and Price Level. Journal of Futures Markets, 33(1): 55-76.

ap Gwilym, O., Buckle, M., and Thomas, S. (1997). The intraday behavior of bid-ask spreads, returns, and volatility for FTSE-100 Stock Index Options. Journal of Derivatives 4, 20-32.

Arnold, T., Erwin, G., Nail, L., and Nixon, T. (2006). Do option markets substitute for stock markets? Evidence from trading on anticipated tender offer announcements. International Review of Financial Analysis, 15(3): 247-255.

Atilgan, Y., Bali, T. G., and Demirtas, K. O. (2015). Implied volatility spreads and expected market returns. Journal of Business \& Economic Statistics, 33(1): 87-101.

Bakshi, G., and Madan, D. (2000). Spanning and derivative-security valuation. Journal of Financial Economics, 55(2): 205-238.

Bakshi, G., Kapadia, N., and Madan, D. (2003). Stock return characteristics, skew laws, and the differential pricing of individual equity options. Review of Financial Studies, 16(1): 101-143.

Bali, T. G., and Hovakimian, A. (2009). Volatility spreads and expected stock returns. Management Science, 55(11): 1797-1812.

Battalio, R., and Schultz, P. (2006). Options and the bubble. The Journal of Finance, 61(5): 2071-2102.

Battalio, R., and Schultz, P. (2011). Regulatory uncertainty and market liquidity: The 2008 short sale ban's impact on equity option markets. The Journal of Finance, 66(6): 2013-2053.

Battalio, R., Hatch, B., and Jennings, R. (2001). Does a National Market System Exist for U.S. ExchangeListed Equity Options?: An Analysis of Multiple-Traded Equity Options The Journal of Finance, 57(2): 931-958.

Benkert, C. (2003). Explaining credit default swap premia. Journal of Futures Markets, 24(1): 71-92.

Berkman, H. (1993). The market spread, limit orders, and options. Journal of Financial Services Research, 6(4): 399-415.

Bernales, A. (2017). The success of option listings. Journal of Empirical Finance, 40: 139-161.

Bernales, A., and Guidolin, M. (2014). Can we forecast the implied volatility surface dynamics of equity options? Predictability and economic value tests. Journal of Banking \& Finance, 46: 326-342.

Bernales, A., and Guidolin, M. (2015). Learning to smile: Can rational learning explain predictable dynamics in the implied volatility surface? Journal of Financial Markets, 26: 1-37.

Bernales, A., and Valenzuela, M. (2016). Implied Correlation and Market Returns. Working paper.

Bernales, A., Cañón, C., and Verousis, T. (2018). Bid-Ask Spread and Liquidity Searching Behaviour of Informed Investors in Option Markets. Finance Research Letters 25, 96-106.

Bernales, A., Chen, L., and Valenzuela, M. (2017). Learning and forecasts about option returns through the volatility risk premium. Journal of Economic Dynamics and Control, 82: 312-330.

Bernales, A., Cortazar, G., Salamunic, L. and Skiadopoulos, G., 2019. Learning and Index Option Returns. Journal of Business \& Economic Statistics, forthcoming.

Bernales, A., Verousis, T., and Voukelatos, N. (2016). Do investors follow the herd in option markets? Forthcoming in Journal of Banking \& Finance.

Bhattacharya, M. (1987). Price changes of related securities: The case of call options and stocks. Journal of Financial and Quantitative Analysis, 22(01): 1-15.

Billings, M. B., and Jennings, R. (2011). The option market's anticipation of information content in earnings announcements. Review of Accounting Studies, 16(3): 587-619.

Black, F., and Scholes, M. (1973). The pricing of options and corporate liabilities. Journal of political economy, 81(3): 637-654.

Blau, B. M., and Wade, C. (2013). Comparing the information in short sales and put options. Review of Quantitative Finance and Accounting, 41(3): 567-583.

Bollen, N. P. (1998). A note on the impact of options on stock return volatility. Journal of Banking \& Finance, 22(9): 1181-1191.

Bondarenko, 0., 2003, Why are put options so expensive?, working paper, University of Illinois, Chicago.

Borochin, P., and Yang, J. (2017). Options, equity risks, and the value of capital structure adjustments. Journal of Corporate Finance, 42: 150-178.

Boyer, B. H., and Vorkink, K. (2014). Stock options as lotteries. The Journal of Finance, 69(4): 1485-1527.

Britten-Jones, M., and Neuberger, A. (2000). Option prices, implied price processes, and stochastic volatility. The Journal of Finance, 55(2): 839-866.

Câmara, A., Popova, I., and Simkins, B. (2012). A comparative study of the probability of default for global financial firms. Journal of Banking \& Finance, 36(3): 717-732.

Cao, C., Chen, Z., and Griffin, J. M. (2005). Informational content of option volume prior to takeovers. The Journal of Business, 78(3): 1073-1109. 
Cao, J., and Han, B. (2013). Cross section of option returns and idiosyncratic stock volatility. Journal of Financial Economics, 108(1): 231-249.

Cao, M., and Wei, J. (2010). Option market liquidity: Commonality and other characteristics. Journal of Financial Markets, 13(1): 20-48.

Capuano, C. (2008). The Option-iPoD: The probability of default implied by option prices based on entropy. IMF Working Paper No. 08/194.

Carr, P., and Wu, L. (2011). A simple robust link between American puts and credit protection. The Review of Financial Studies, 24(2): 473-505.

Castagna, A., and Matolcsy, Z. (1982). A two stage experimental design to test the efficiency of the market for traded stock options and the Australian evidence. Journal of Banking \& Finance, 6(4): 521-532.

Chakravarty, S., Gulen, H., and Mayhew, S. (2004). Informed trading in stock and option markets. The Journal of Finance, 59(3): 1235-1257.

Chan, K., Chung, Y. P., and Fong, W.-M. (2002). The informational role of stock and option volume. Review of Financial Studies, 15(4): 1049-1075.

Chan, K., Chung, Y. P., and Johnson, H. (1995). The intraday behavior of bid-ask spreads for NYSE stocks and CBOE options. Journal of Financial and Quantitative Analysis, 30(03): 329-346.

Chang, B. Y., and Orosi, G. (2016). Equity Option Implied Probability of Default and Equity Recovery Rate. Journal of Futures Markets, 37(6): 599-613.

Chen, N., and Kou, S. G. (2009). Credit spreads, optimal capital structure, and implied volatility with endogenous default and jump risk. Mathematical Finance, 19(3): 343-378.

Chen, Y., and Gau, Y. (2009). Tick sizes and relative rates of price discovery in stock, futures, and options markets: Evidence from the Taiwan stock exchange. Journal of Futures Markets, 29(1): 74-93.

Chiang, R., and Fong, W.-M. (2001). Relative informational efficiency of cash, futures, and options markets: The case of an emerging market. Journal of Banking and Finance, 25(2): 355-375.

Cho, Y.-H., and Engle, R. F. (1999). Modeling the impacts of market activity on bid-ask spreads in the option market. Working Paper.

Christensen, Bent J. and Nagpurnanand R. Prabhala. 1998. "The Relation between Implied and Realized Volatility," J. Finan. Econ. 50:2, pp. 125-50.

Christoffersen, P., Goyenko, R., Jacobs, K., and Karoui, M. (2017). Illiquidity premia in the equity options market. Working Paper.

Conrad, J. (1989). The price effect of option introduction. The Journal of Finance, 44(2): 487-498.

Conrad, J. S., Dittmar, R. F., and Hameed, A. (2017). Cross-market and cross-firm effects in implied default probabilities and recovery values. Working Paper.

Conrad, J., Dittmar, R. F., and Ghysels, E. (2013). Ex ante skewness and expected stock returns. The Journal of Finance, 68(1): 85-124.

Constantinides, G. M., Jackwerth, J. C., \& Savov, A. (2013). The puzzle of index option returns. Review of Asset Pricing Studies, 3(2), 229-257.

Coval, J. D., and Shumway, T. (2001). Expected option returns. The Journal of Finance, 56(3): 983-1009.

Cremers, M., and Weinbaum, D. (2010). Deviations from Put-Call Parity and Stock Return Predictability. Journal of Financial and Quantitative Analysis, 45(02): 335-367.

Cremers, M., Driessen, J., Maenhout, P., and Weinbaum, D. (2008). Individual stock-option prices and credit spreads. Journal of Banking \& Finance, 32(12): 2706-2715.

Da Fonseca, J., and Gottschalk, K. (2014). Cross-hedging strategies between CDS spreads and option volatility during crises. Journal of International Money and Finance, 49: 386-400.

Damodaran, A., and Lim, J. (1991). The effects of option listing on the underlying stocks' return processes. Journal of Banking \& Finance, 15(3): 647-664.

Danielsen, B. R., and Sorescu, S. M. (2001). Why do option introductions depress stock prices? A study of diminishing short sale constraints. Journal of Financial and Quantitative Analysis, 36(4): 451-484.

Danielsen, B. R., Van Ness, B. F., and Warr, R. S. (2007). Reassessing the impact of option introductions on market quality: A less restrictive test for event-date effects. Journal of Financial and Quantitative Analysis, 42(4): 1041-1062.

Dennis, P., Mayhew, S., and Stivers, C. (2006). Stock returns, implied volatility innovations, and the asymmetric volatility phenomenon. Journal of Financial and Quantitative Analysis, 41(02): 381406.

Detemple, J., and Jorion, P. (1990). Option listing and stock returns: An empirical analysis. Journal of Banking \& Finance, 14(4): 781-801.

Detemple, J., and Selden, L. (1991). A general equilibrium analysis of option and stock market interactions. International Economic Review, 32(2): 279-303. 
Diltz, J. D., and Kim, S. (1996). The relationship between stock and option price changes. Financial Review, 31(3): 499-519.

Diz, F., and Finucane, T. J. (1993). The rationality of early exercise decisions: Evidence from the S\&P 100 index options market. The Review of Financial Studies, 6(4): 765-797.

Donders, M., Kouwenberg, R., and Vorst, T. (2000). Options and earnings announcements: an empirical study of volatility, trading volume, open interest and liquidity. European Financial Management, 6(2): 149-171.

Dong, W., and Sinha, N. R. (2011). Where do informed traders trade? trading around news on dow 30 options. Working Paper.

Driessen, J., Maenhout, P. J., and Vilkov, G. (2009). The price of correlation risk: Evidence from equity options. The Journal of Finance, 64(3): 1377-1406

Duarte, J., Young, L., 2009. Why is PIN priced? Journal of Financial Economics 91, 119-138.

Easley, D., Kiefer, N. M., O’Hara, M., Paperman, J. B., 1996. Liquidity, information, and infrequently traded stocks. Journal of Finance 51, 1405-1436.

Easley, D., O'Hara, M., Paperman, J. B., 1998a. Financial analysts and information-based trade. Journal of Financial Markets 1, 175-201.

Easley, D., O'Hara, M., Srinivas, P. S., 1998b. Option volume and stock prices: Evidence on where informed traders trade. Journal of Finance 53, 431-465.

Easley, David, Nicholas M. Kiefer, and Maureen O'Hara, 1997, One day in the life of a very common stock, Review of Financial Studies 10, 805-835.

Evnine, J., and Rudd, A. (1985). Index options: The early evidence. The Journal of Finance, 40(3): 743-756.

Faccini R., Konstantinidi E., Skiadopoulos G., Sarantopoulou S. (2018) "A New Predictor of U.S. Real conomic Activity: The S\&P 500 Option Implied Risk Aversion", Management Science, (forthcoming).

Faff, R., and Hillier, D. (2005). Complete markets, informed trading and equity option introductions. Journal of Banking \& Finance, 29(6): 1359-1384.

Fama, E. F. (1970). Efficient capital markets: A review of theory and empirical work. The Journal of Finance, 25(2): 383-417.

Fan, R., Taylor, S. J., and Sandri, M. (2017). Density forecast comparisons for stock prices, obtained from high-frequency returns and daily option prices. Journal of Futures Markets, 31(1): 83-103.

Fedenia, M., and Grammatikos, T. (1992). Options trading and the bid-ask spread of the underlying stocks. Journal of Business: 335-351.

Flint, A., Lepone, A., and Yang, J. Y. (2014). Do Option Strategy Traders Have a Disadvantage? Evidence from the Australian Options Market. Journal of Futures Markets, 34(9): 838-852.

Freund, S., McCann, P. D., and Webb, G. P. (1994). A Regression Analysis of the Effects of Options Introduction on Stock Variances. The Journal of Derivatives, 1(3): 25-38.

Fu, X., Arisoy, Y. E., Shackleton, M. B., and Umutlu, M. (2016). Option-Implied Volatility Measures and Stock Return Predictability. The Journal of Derivatives, 24(1): 58-78.

Galai, D. (1978). Empirical tests of boundary conditions for CBOE options. Journal of Financial Economics, 6(2-3): 187-211.

Gjerde, Ø., and Saettem, F. (1995). Option initiation and underlying market behavior: Evidence from Norway. Journal of Futures Markets, 15(8): 881-899.

Goncalves, S., \& Guidolin, M. (2006). Predictable dynamics in the S\&P 500 index options implied volatility surface. The Journal of Business, 79(3), 1591-1635.

Govindaraj, S., Jin, W., Livnat, J., and Zhao, C. (2014). Using Option Implied Volatilities to Predict Absolute Stock Returns-Evidence from Earnings Announcements and Annual Shareholders' Meetings. Working Paper.

Goyal, A., and Saretto, A. (2009). Cross-section of option returns and volatility. Journal of Financial Economics, 94(2): 310-326.

Goyenko, R., Ornthanalai, C., and Tang, S. (2015). Options Illiquidity: Determinants and Implications for Stock Returns. Rotman School of Management Working Paper No. 2492506.

Hamill, P. A., Opong, K. K., and McGregor, P. (2002). Equity option listing in the UK: a comparison of market-based research methodologies. Journal of Empirical Finance, 9(1): 91-108.

Han, B., and Zhou, Y. (2012). Variance risk premium and cross-section of stock returns. Working Paper.

Hao, J., Kalay, A., and Mayhew, S. (2010). Ex-dividend arbitrage in option markets. Review of Financial Studies, 23(1): 271-303.

Harris, L. (1989). S\&P 500 cash stock price volatilities. The Journal of Finance, 44(5): 1155-1175.

Hayunga, D. K., and Lung, P. P. (2014). Trading in the options market around financial analysts' consensus revisions. Journal of Financial and Quantitative Analysis, 49(3): 725-747. 
Holowczak, R., Simaan, Y. E., and Wu, L. (2006). Price discovery in the US stock and stock options markets: A portfolio approach. Review of Derivatives Research, 9(1): 37-65.

Hsieh, Wen-liang, G., and Huei-Ru He, 2014, "Informed trading, trading strategies and the information content of trading volume: Evidence from the Taiwan index options market." Journal of International Financial Markets, Institutions and Money 31: 187-215.

Jennings, R., and Starks, L. (1986). Earnings announcements, stock price adjustment, and the existence of option markets. The Journal of Finance, 41(1): 107-125.

Jin, W., Livnat, J., and Zhang, Y. (2012). Option Prices Leading Equity Prices: Do Option Traders Have an Information Advantage? Journal of Accounting Research, 50(2): 401-432.

Johnson, T. L., and So, E. C. (2012). The option to stock volume ratio and future returns. Journal of Financial Economics, 106(2): 262-286.

Johnson, T., Liang, M., and Liu, Y. (2016). What Drives Index Options Exposures? Review of Finance, 22(2): 561-593.

Jones, C., 2006, A nonlinear factor analysis of S\&P 500 index option returns, Journal of Finance 41, 23252363.

Kang, J., and Park, H.-J. (2008). The information content of net buying pressure: Evidence from the KOSPI 200 index option market. Journal of Financial Markets, 11(1): 36-56.

Kaul, G., Nimalendran, M., and Zhang, D. (2004). Informed trading and option spreads. Working Paper.

Kita, A. (2012). CDS spreads explained with credit spread volatility and jump risk of individual firms. Working Paper.

Kumar, R., Sarin, A., and Shastri, K. (1995). The impact of index options on the underlying stocks: The evidence from the listing of Nikkei stock average options. Pacific-Basin Finance Journal, 3(2-3): 303-317.

Kumar, R., Sarin, A., and Shastri, K. (1998). The impact of options trading on the market quality of the underlying security: An empirical analysis. The Journal of Finance, 53(2): 717-732.

Lakonishok, J., Lee, I., Pearson, N. D., and Poteshman, A. M. (2007). Option Market Activity. Review of Financial Studies, 20(3): 813-857.

Lamoureux, C. G., and Lastrapes, W. D. (1993). Forecasting stock-return variance: Toward an understanding of stochastic implied volatilities. The Review of Financial Studies, 6(2): 293-326.

Latane, H. A., and Rendleman, R. J. (1976). Standard deviations of stock price ratios implied in option prices. The Journal of Finance, 31(2): 369-381.

Lemmon, M., and Ni, S. X. (2014). Differences in trading and pricing between stock and index options. Management Science, 60(8): 1985-2001.

Levy, H., and Yoder, J. A. (1993). The behavior of option implied standard deviations around merger and acquisition announcements. Financial Review, 28(2): 261-272.

Lin, T.-C., and Lu, X. (2015). Why do options prices predict stock returns? Evidence from analyst tipping. Journal of Banking \& Finance, 52: 17-28.

Liu, S. (2010). Equity Options and Underlying Stocks' Behavior: Further Evidence from Japan*. International Review of Finance, 10(3): 293-312.

Liu, X., Pong, E. S., Shackleton, M. B., and Zhang, Y. (2014). Option-implied volatilities and stock returns: evidence from industry-neutral portfolios. The Journal of Portfolio Management, 41(1): 65-77.

Lung, P. P., and Xu, P. (2014). Tipping and option trading. Financial management, 43(3): 671-701.

Maberly, E. D., Pierce, R. M., and Catania, P. (2010). Threshold levels, strike price grid, and other market microstructure issues associated with exchange-traded equity options. Journal of Futures Markets, 30(2): 188-201.

Manaster, S., and Rendleman, R. J. (1982). Option prices as predictors of equilibrium stock prices. The Journal of Finance, 37(4): 1043-1057.

Mayhew, S. (2002). Competition, Market Structure, and Bid-Ask Spreads in Stock Option Markets. The Journal of Finance, 57(2): 931-958.

Mayhew, S., and Mihov, V. (2000). Another look at option listing effects. Working Paper.

Mayhew, S., and Mihov, V. (2004). How do exchanges select stocks for option listing? The Journal of Finance, 59(1): 447-471.

Mayhew, S., and Stivers, C. (2003). Stock return dynamics, option volume, and the information content of implied volatility. Journal of Futures Markets, 23(7): 615-646.

Mayhew, S., Sarin, A., and Shastri, K. (1999). What drives option liquidity? Working Paper.

Mazouz, K. (2004). The effect of CBOE option listing on the volatility of NYSE traded stocks: a timevarying variance approach. Journal of Empirical Finance, 11(5): 695-708.

Muravyev, D., Pearson, N. D., and Paul Broussard, J. (2013). Is there price discovery in equity options? Journal of Financial Economics, 107(2): 259-283. 
Neal, R. (1987). Potential competition and actual competition in equity options. The Journal of Finance, 42(3): 511-531.

Ni, S. X. (2008). Stock option returns: A puzzle. Working Paper.

Ni, S. X., Pearson, N. D., and Poteshman, A. M. (2005). Stock price clustering on option expiration dates. Journal of Financial Economics, 78(1): 49-87.

Nordén, L. (2001). Hedging of American equity options: do call and put prices always move in the direction as predicted by the movement in the underlying stock price? Journal of Multinational Financial Management, 11(4): 321-340.

Odders-White, Elizabeth R., and Mark J. Ready, 2008, The probability and magnitude of information events,Journal of Financial Economics 87, 227-248.

Pan, J., and Poteshman, A. M. (2006). The Information in Option Volume for Future Stock Prices. Review of Financial Studies, 19(3): 871-908.

Patell, J. M., and Wolfson, M. A. (1979). Anticipated information releases reflected in call option prices. Journal of Accounting and Economics, 1(2): 117-140.

Pinder, S. (2003). An empirical examination of the impact of market microstructure changes on the determinants of option bid-ask spreads. International Review of Financial Analysis, 12(5): 563577.

Poteshman, A. M., and Serbin, V. (2003). Clearly irrational financial market behavior: Evidence from the early exercise of exchange traded stock options. The Journal of Finance, 58(1): 37-70.

Rahman, S. (2001). The introduction of derivatives on the Dow Jones Industrial Average and their impact on the volatility of component stocks. Journal of Futures Markets 21(7): 633-653.

Rehman, Z., and Vilkov, G. (2012). Risk-neutral skewness: Return predictability and its sources. Working Paper.

Roll, R., Schwartz, E., and Subrahmanyam, A. (2010). O/S: The relative trading activity in options and stock. Journal of Financial Economics, 96(1): 1-17.

Rubinstein, M. (1985). Nonparametric tests of alternative option pricing models using all reported trades and quotes on the 30 most active CBOE option classes from August 23, 1976 through August 31, 1978. The Journal of Finance, 40(2): 455-480.

Ryu, D. (2015). The information content of trades: An analysis of KOSPI 200 index derivatives. Journal of Futures Markets, 35(3): 201-221.

Sahlström, P. (2001). Impact of stock option listings on return and risk characteristics in Finland. International Review of Financial Analysis, 10(1): 19-36.

Schlag, C., and Stoll, H. (2005). Price impacts of options volume. Journal of Financial Markets, 8(1): 69-87.

Segara, L., and Sagara, R. (2007). Intraday trading patterns in the equity warrants and equity options markets: Australian evidence. Australasian Accounting, Business and Finance Journal, 1(2): 42-60.

Sheikh, A. M., and Ronn, E. I. (1994). A characterization of the daily and intraday behavior of returns on options. The Journal of Finance, 49(2): 557-580.

Sim, M., Ryu, D., and Yang, H. (2016). Tests on the monotonicity properties of KOSPI 200 options prices. Journal of Futures Markets, 36(7): 625-646.

Skinner, D. J. (1989). Options markets and stock return volatility. Journal of Financial Economics, 23(1): 61-78.

Stephan, J. A., and Whaley, R. E. (1990). Intraday price change and trading volume relations in the stock and stock option markets. The Journal of Finance, 45(1): 191-220.

Taylor, S. J., Tzeng, C. F., and Widdicks, M. (2014). Bankruptcy probabilities inferred from option prices. The Journal of Derivatives, 22(2): 8-31.

Taylor, S. J., Yadav, P. K., and Zhang, Y. (2010). The information content of implied volatilities and modelfree volatility expectations: Evidence from options written on individual stocks. Journal of Banking \& Finance, 34(4): 871-881.

Van Buskirk, A. (2011). Volatility skew, earnings announcements, and the predictability of crashes. Working Paper.

Vasquez, A. (2017). Equity Volatility Term Structures and the Cross Section of Option Returns. Forthcoming in Journal of Financial and Quantitative Analysis.

Verousis, T., and ap Gwilym, O. (2013). The Microstructure of Individual Equity Options: Firm-Level and Common Effects on Liquidity. Working Paper.

Verousis, T., ap Gwilym, O., and Voukelatos, N. (2015). The Impact of a Premium-Based Tick Size on Equity Option Liquidity. Journal of Futures Markets, 36(4): 397-417.

Verousis, T., ap Gwilym, O., and Voukelatos, N. (2016). Commonality in equity options liquidity: evidence from European Markets. The European Journal of Finance, 22(12): 1204-1223.

Vijh, A. M. (1990). Liquidity of the CBOE equity options. The Journal of Finance, 45(4): 1157-1179. 
Vilsmeier, J. (2016). Updating the option implied probability of default methodology. Journal of computational finance, 19(3): 1-27.

Wang, H., Zhou, H., and Zhou, Y. (2013). Credit default swap spreads and variance risk premia. Journal of Banking \& Finance, 37(10): 3733-3746.

Watt, W. H., Yadav, P. K., and Draper, P. (1992). The impact of option listing on underlying stock returns: The UK evidence. Journal of Business Finance \& Accounting, 19(4): 485-503.

Wei, J., and Zheng, J. (2010). Trading activity and bid-ask spreads of individual equity options. Journal of Banking \& Finance, 34(12): 2897-2916.

Wu, W.-S., Liu, Y.-J., Lee, Y.-T., and Fok, R. C. W. (2014). Hedging costs, liquidity, and inventory management: The evidence from option market makers. Journal of Financial Markets, 18: 25-48.

Xing, Y., Zhang, X., and Zhao, R. (2010). What Does Individual Option Volatility Smirks Tell Us about Future Equity Returns. Journal of Financial and Quantitative Analysis, 45(3): 641-662. 
Table 1: Impact of option listing on the equity market

\begin{tabular}{|c|c|c|c|}
\hline \multicolumn{4}{|c|}{ Panel A: Introduction of new equity options into the market } \\
\hline & Market & Period & Main findings \\
\hline Mayhew and Mihov (2004) & US & $1973-1996$ & $\begin{array}{l}\text { Exchanges tend to list options on stocks with high trading volume, volatility, and } \\
\text { market capitalization. }\end{array}$ \\
\hline Danielsen et al. (2007) & US & $1993-2002$ & The size of a stock's bid-ask spread is the single most important option-listing determinant. \\
\hline Bernales (2017) & US & $1996-2009$ & A high level of asymmetric information predicts option adoption rates. \\
\hline \multicolumn{4}{|c|}{ Panel B: Short-term impact of option listing on the equity market } \\
\hline & Market & Period & Main findings \\
\hline Detemple and Jorion (1990) & US & $1973-1986$ & $\begin{array}{l}\text { Positive impact on individual stock returns and volatility. The positive impact decreases after } \\
\text { index options are introduced. }\end{array}$ \\
\hline Watt et al. (1992) & UK & $1978-1989$ & Positive impact on stock returns. \\
\hline Freund et al. (1994) & US & $1973-1990$ & Positive impact on volatility. Negative impact of put listing on stock returns. \\
\hline Gjerde and Saettem (1995) & Norway & $1990-1994$ & Positive impact on stock returns. \\
\hline Bollen (1998) & US & $1987-1992$ & Positive impact on stock returns. \\
\hline Danielsen and Sorescu (2001) & US & $1973-1995$ & $\begin{array}{l}\text { The negative impact of the introduction of equity options on the underlying stock prices is } \\
\text { consistent with the mitigation of short-sale constraints. }\end{array}$ \\
\hline \multicolumn{4}{|c|}{ Panel C: Long-term impact of option listing on the equity market } \\
\hline & Market & Period & Main findings \\
\hline Jennings and Starks (1986) & US & $1981-1982$ & Volatility decreases after option listing. \\
\hline Conrad (1989) & US & $1974-1980$ & Positive impact on stock prices. \\
\hline Skinner (1989) & US & $1973-1985$ & Volatility decreases after option listing. \\
\hline Damodaran and Lim (1991) & US & $1973-1983$ & Volatility decreases after option listing. \\
\hline Fedenia and Grammatikos (1992) & US & $1970-1988$ & Optioned stocks have higher liquidity. \\
\hline Kumar et al. (1998) & US & $1983-1989$ & $\begin{array}{l}\text { Higher liquidity, lower information asymmetry, and improved price efficiency for optioned } \\
\text { stocks. }\end{array}$ \\
\hline Mayhew and Mihov (2000) & US & $1973-1996$ & Impact on stock prices was positive pre-1981 and turned negative post-1981. \\
\hline
\end{tabular}




\begin{tabular}{|c|c|c|c|}
\hline Sahlstrom (2001) & Finland & $1992-1995$ & Narrower bid-ask spreads for option stocks. \\
\hline Mayhew and Mihov (2004) & US & $1973-1966$ & $\begin{array}{l}\text { No evidence that volatility declines with option introduction, using control-sample } \\
\text { methodology designed to correct for the endogeneity of option listing. }\end{array}$ \\
\hline Mazouz (2004) & US & $1973-2001$ & No impact on stock volatility after accounting for changes in market-wide volatility. \\
\hline Faff and Hillier (2005) & UK & $1973-1995$ & Stocks with options tend to exhibit higher volatility. \\
\hline Ni et al. (2005) & US & $1996-2002$ & Negative impact, with stock prices clustering around options' strike prices on expiration dates. \\
\hline Danielsen et al. (2007) & US & $1993-2002$ & $\begin{array}{l}\text { Options do not systematically improve the market liquidity of the underlying security; rather, } \\
\text { the market liquidity of the underlying security improves before the decision to list is made. }\end{array}$ \\
\hline Liu (2010) & Japan & $1997-2007$ & Stocks with options tend to exhibit higher volatility. \\
\hline Agyei-Ampomah and Mazouz (2011) & UK & $1986-2007$ & Optioned stocks co-move more, leading to reduced diversification benefits. \\
\hline Bernales (2017) & US & $1996-2009$ & Levels of asymmetric information are reduced after equity option introduction. \\
\hline
\end{tabular}


Table 2: Market efficiency issues

\begin{tabular}{|c|c|c|c|}
\hline \multicolumn{4}{|c|}{ Panel A: Option mispricing } \\
\hline & Market & Period & Main findings \\
\hline Galai (1978) & US & 1973 & Simultaneous prices of stocks and options are not fully synchronized. \\
\hline Castagna and Matolcsy (1982) & Australia & $1976-1977$ & No opportunity for arbitrate profits after accounting for transaction costs. \\
\hline Norden (2001) & Sweden & $1995-1996$ & Equity option prices do not move as expected after stock price changes. \\
\hline Battalio and Schultz (2006) & US & 2000 & No evidence of arbitrage opportunities during the 2000 short-sale ban. \\
\hline Battalio and Schultz (2011) & US & 2008 & Significant arbitrage opportunities during the 2008 short-sale ban. \\
\hline \multicolumn{4}{|c|}{ Panel B: Abnormal returns on individual equity options } \\
\hline & Market & Period & Main findings \\
\hline Sheikh and Ronn (1994) & US & $1986-1987$ & Intraday option returns have patterns that show evidence of informed trading. \\
\hline $\mathrm{Ni}(2008)$ & US & $1996-2005$ & $\begin{array}{l}\text { Option returns deviate significantly from theoretical predictions. Option traders are seeking } \\
\text { idiosyncratic skewness. }\end{array}$ \\
\hline Driessen et al. (2009) & US & $1996-2003$ & Trading strategy exploiting priced correlation risk generating abnormal returns. \\
\hline Goyal and Saretto (2009) & US & $1996-2006$ & The volatility gap can explain the cross-section of option returns. Significant mispricing detected. \\
\hline Boyer and Vorkink (2014) & US & $1996-2009$ & $\begin{array}{l}\text { Option returns are negatively related to ex-ante skewness. Abnormal returns of option portfolios } \\
\text { with high ex-ante skewness. }\end{array}$ \\
\hline Cao and Han (2013) & US & $1996-2009$ & $\begin{array}{l}\text { Delta-hedged option returns behave abnormally since they are shown to be negatively related to } \\
\text { the idiosyncratic volatility of the underlying stocks. }\end{array}$ \\
\hline Vasquez (2017) & US & $1996-2012$ & Abnormal option returns from strategies based on the implied volatility term structure. \\
\hline
\end{tabular}


Table 3: Option market microstructure and investor behaviour departing from rationality

\begin{tabular}{|c|c|c|c|}
\hline \multicolumn{4}{|c|}{ Panel A: Liquidity patterns } \\
\hline & Market & Period & Main findings \\
\hline Vijh (1990) & US & 1988 & Options have greater market depth than stocks, due to having multiple dealers per contract. \\
\hline Berkman (1993) & Europe & 1989 & Competition in the limit order book improves liquidity. \\
\hline Aggarwal and Gruca (1993) & US & 1986 & L-shaped pattern of option bid-ask spread. \\
\hline Chan et al. (1995) & US & 1986 & L-shaped pattern of option bid-ask spread. \\
\hline Mayhew et al. (1999) & US & 1993 & $\begin{array}{l}\text { Option liquidity is related to the price volatility, trading volume, and firm size of the underlying } \\
\text { stock. }\end{array}$ \\
\hline Segara and Sagara (2007) & Australia & 2000 & L-shaped pattern of option bid-ask spread. \\
\hline Lakonishok et al. (2007) & US & $1990-2001$ & Liquidity is driven by market makers' hedging costs, but not by volatility trading. \\
\hline Cao and Wei (2010) & US & $1996-2004$ & Information asymmetry drives liquidity. \\
\hline Wei and Zheng (2010) & US & $1996-2007$ & Evidence of maturity substitution and moneyness substitution among different options. \\
\hline Maberly et al. (2010) & US & $1973-2008$ & Market microstructure issues (e.g. price thresholds) have a significant impact on liquidity. \\
\hline ap Gwilym and Verousis (2013) & Europe & 2005 & The market-maker scheme drives price clustering. \\
\hline Verousis and ap Gwilym (2013) & Europe & $2008-2010$ & Option liquidity is negatively related to stock volatility. \\
\hline Flint et al. (2014) & Australia & 2007 & Bid-ask spreads of equity options are affected by the cost of hedging. \\
\hline Christoffersen et al. (2017) & US & $2004-2012$ & $\begin{array}{l}\text { Option liquidity is driven by asymmetric information, hedging and inventory costs, stock } \\
\text { illiquidity, and option order imbalances. }\end{array}$ \\
\hline Goyenko et al. (2015) & US & $2004-2013$ & Liquidity is driven by market makers' hedging costs. \\
\hline Verousis et al. (2016) & Europe & $2008-2010$ & $\begin{array}{l}\text { Information asymmetry and hedging costs drive liquidity, with volume and volatility positively } \\
\text { related to the bid-ask spread. }\end{array}$ \\
\hline \multicolumn{4}{|c|}{ Panel B: Impact of market microstructure changes } \\
\hline & Market & Period & Main findings \\
\hline Neal (1987) & US & $1985-1986$ & Listing on multiple option exchanges lowers transaction costs. \\
\hline Battalio et al. (2001) & US & 2000 & Trading in a national market system leads to improved quality of execution and lower spreads. \\
\hline Mayhew (2002) & US & $1986-1997$ & Listing on multiple option exchanges lowers transaction costs. \\
\hline Pinder (2003) & Australia & $1995-1999$ & Order-driven system results in lower bid-ask spreads. \\
\hline
\end{tabular}




\begin{tabular}{|c|c|c|c|}
\hline Anand and Weaver (2006) & US & 1999 & Designating primary market makers leads to lower quoted and effective spreads. \\
\hline Battalio and Schultz (2011) & US & 2008 & Spreads increased for stocks that were the object of the short-sale ban. \\
\hline Verousis and ap Gwilym (2013) & Europe & $2008-2010$ & Option liquidity dropped after the short-sale ban. \\
\hline Verousis et al. (2015) & Europe & $2009-2010$ & Reducing the tick size resulted in smaller spreads but lower depths. \\
\hline Anand et al. (2016) & US & $2007-2013$ & $\begin{array}{l}\text { A make-take structure increases quote competition among market makers, reducing execution } \\
\text { costs. }\end{array}$ \\
\hline \multicolumn{4}{|c|}{ Panel C: Investor behaviour departing from rationality } \\
\hline & Market & Period & Main findings \\
\hline Poteshman and Serbin (2003) & US & $1996-1999$ & Evidence of irrational early exercise of American-style options. \\
\hline Hao et al. (2010) & US & 2003 & Option investors regularly fail to exercise options rationally before ex-dividend dates. \\
\hline Lemmon and $\mathrm{Ni}$ (2014) & US & $1990-2010$ & $\begin{array}{l}\text { The demand for individual equity options that increases exposure to the underlying is positively } \\
\text { related to the individual investor sentiment and past market returns. }\end{array}$ \\
\hline Bernales et al. (2016) & US & $1996-2012$ & Option investors herd around the consensus during periods of market stress. \\
\hline
\end{tabular}


Table 4: Price discovery

\begin{tabular}{|c|c|c|c|}
\hline \multicolumn{4}{|c|}{ Panel A: Agent-driven studies } \\
\hline & Market & Period & Main findings \\
\hline Kaul et al. (2004) & US & 1995 & Informed investors trade strategically in the equity option market. \\
\hline Anand and Chakravarty (2007) & US & 1999 & Evidence of stealth trading in equity option markets. \\
\hline Bernales et al. (2018) & US & $1996-2009$ & $\begin{array}{l}\text { The option bid-ask spread may still be a good proxy for informed trading, despite the liquidity- } \\
\text { searching behaviour of informed agents. }\end{array}$ \\
\hline Stephan and Whaley (1990) & US & 1986 & The equity market leads options in price discovery. \\
\hline Chan et al. (2002) & US & 1995 & $\begin{array}{l}\text { The stock trading volume can predict option quote revisions, but the option trading volume has } \\
\text { no predictive ability. }\end{array}$ \\
\hline Holowczak et al. (2006) & US & $1990-2001$ & The equity market leads the option market in price discovery. \\
\hline Muravyev et al. (2013) & US & $2003-2006$ & The equity market leads the option market in price discovery. \\
\hline O'Connor (1999) & US & 1990 & The equity market leads the option market in price discovery. \\
\hline Chakravarty et al. (2004) & US & $1988-1992$ & Informed traders trade in both markets. \\
\hline \multicolumn{4}{|c|}{ Panel B: Event-driven studies } \\
\hline & Market & Period & Main findings \\
\hline Patell and Wolfson (1979) & US & $1974-1978$ & Options reflect anticipated stock volatility increases prior to earnings announcements. \\
\hline Levy and Yoder (1993) & US & $1982-1985$ & Options reflect anticipated stock volatility increases prior to earnings announcements. \\
\hline Donders et al. (2000) & US & $1991-1993$ & Options reflect anticipated stock volatility increases prior to earnings announcements. \\
\hline Atilgan et al. (2015) & US & $1996-2008$ & Options contain incremental information around earnings announcements. \\
\hline Ajinkya and Gift (1985) & US & $1977-1978$ & $\begin{array}{l}\text { Options contain incremental information about the dispersion of analysts' forecasts of earnings } \\
\text { per share. }\end{array}$ \\
\hline Jennings and Starks (1986) & US & $1981-1982$ & Optioned stocks adjust to earnings announcements more efficiently than non-optioned stocks. \\
\hline Amin and Lee (1997) & US & $1988-1989$ & Options contain incremental information around earnings announcements. \\
\hline Roll et al. (2010) & US & $1996-2007$ & Options contain incremental information around earnings announcements. \\
\hline Billings and Jennings (2011) & US & $1996-2006$ & Options contain incremental information around earnings announcements. \\
\hline Hayunga and Lung (2014) & US & $2000-2009$ & Options lead the price discovery process during analysts' revisions. \\
\hline Lung and Xu (2014) & US & $2009-2011$ & Options lead the price discovery process during analysts' revisions, driven by information \\
\hline
\end{tabular}




\begin{tabular}{lccl}
\hline & & & leakage. \\
Dong and Sinha (2011) & US & $2003-2009$ & Options lead the price discovery process around corporate news. \\
Anthony (1988) & US & $1982-1983$ & Abnormal trading volume in options around corporate announcements. \\
Arnold et al. (2006) & US & $1994-2000$ & Abnormal trading volume in options around corporate announcements. \\
Easley et al. (1998a) & US & 1990 & Abnormal trading volume in options around corporate announcements, leading stock price \\
& & changes. \\
\hline
\end{tabular}


Table 5: Option-implied information about stock prices and returns

\begin{tabular}{|c|c|c|c|}
\hline Manaster and Rendleman (1982) & US & $1973-1976$ & Option prices contain information about future movements of stock prices. \\
\hline Bhattacharya (1987) & US & $1977-1978$ & Informational content of option prices regarding future stock prices is economically insignificant. \\
\hline Diltz and Kim (1996) & US & 1988 & Stock prices adjust to the level implied by option prices within two trading days. \\
\hline Easley et al. (1998b) & US & 1990 & Informed option trading volume can predict stock returns, but general trading volume cannot. \\
\hline Cao et al. (2005) & US & $1986-1994$ & Option trading volume can predict stock returns around takeover announcements. \\
\hline Pan and Poteshman (2006) & US & $1990-2001$ & The put-to-call trading volume ratio is negatively related to future stock returns. \\
\hline Bali and Hovakimian (2009) & US & $1996-2004$ & Deviations from put-call parity can predict future stock returns. \\
\hline Cremers and Weinbaum (2010) & US & $1996-2005$ & Deviations from put-call parity can predict future stock returns. \\
\hline Xing et al. (2010) & US & $1996-2005$ & The skewness of the risk-neutral distribution can predict future stock returns. \\
\hline Roll et al. (2010) & US & $1996-2007$ & The option-to-stock trading volume ratio is positively related to future stock returns. \\
\hline Van Buskirk (2011) & US & $1996-2009$ & $\begin{array}{l}\text { The skewness of the risk-neutral distribution can predict stock returns around earnings } \\
\text { announcements. }\end{array}$ \\
\hline Han and Zhou (2012) & US & $1996-2009$ & The variance risk premium can predict future stock returns. \\
\hline Jin et al. (2012) & US & $1996-2010$ & $\begin{array}{l}\text { The skewness of the risk-neutral distribution and deviations from put-call parity can predict } \\
\text { stock returns. }\end{array}$ \\
\hline Rehman and Vilkov (2012) & US & $1996-2011$ & Risk-neutral skewness is positively related to future stock returns. \\
\hline Johnson and So (2012) & US & $1996-2008$ & The option-to-stock trading volume ratio is negatively related to future stock returns. \\
\hline Blau and Wade (2013) & US & Not specified & $\begin{array}{l}\text { The put-to-call trading volume ratio predicts stock returns, but the short-sales to total stock } \\
\text { trading volume ratio subsumes that information. }\end{array}$ \\
\hline Conrad et al. (2013) & US & $1996-2005$ & Risk-neutral skewness can predict future stock returns. \\
\hline Govindaraj et al. (2014) & US & $1996-2011$ & $\begin{array}{l}\text { The volatility of the risk-neutral distribution can predict future stock prices, especially during } \\
\text { firm-specific events. }\end{array}$ \\
\hline Liu et al. (2014) & US & $1996-2011$ & $\begin{array}{l}\text { The skewness of the risk-neutral distribution and deviations from put-call parity can predict } \\
\text { stock returns. }\end{array}$ \\
\hline Lin and $\mathrm{Lu}(2015)$ & US & $1996-2010$ & $\begin{array}{l}\text { The volatility of the risk-neutral distribution can predict future stock prices, especially during } \\
\text { firm-specific events. }\end{array}$ \\
\hline
\end{tabular}




\section{Goyenko et al. (2015)}

Fu et al. (2016)

Bernales and Valenzuela (2016)

Borochin and Yang (2017)

\section{US}

US

US
$2004-2013$

$1996-2014$

$1996-2010$

$1996-2012$

$2003-2012$
Option-induced order flows can predict stock returns during periods of option illiquidity.

The skewness of the risk-neutral distribution, deviations from put-call parity, and the variance risk premium can predict future stock returns.

The option-implied correlation obtained from 100 stock options (where the underlying stocks are part of the S\&P 100 index) is an indicator of market-wide risk and contains information on future market returns.

The skewness of the risk-neutral distribution and deviations from put-call parity can predict future stock returns, due to expected leverage changes.

The risk-neutral distribution can predict future realized distributions. 
Table 6: Option-implied information about the stock return volatility

\begin{tabular}{|c|c|c|c|}
\hline & Market & Period & Main findings \\
\hline Latane and Rendleman (1976) & US & $1973-1974$ & At-the-money (ATM) implied volatility forecasts future volatility better than historical measures. \\
\hline Lamoureux and Lastrapes (1993) & US & $1982-1984$ & Implied volatility helps to predict future volatility. \\
\hline Mayhew and Stivers (2003) & US & $1988-1995$ & ATM implied volatility forecasts future volatility efficiently only for stocks with liquid options. \\
\hline Cao et al. (2006) & US & $1996-2004$ & ATM implied volatility forecasts future volatility better than historical measures. \\
\hline Dennis et al. (2006) & US & $1988-1995$ & ATM implied volatility forecasts future volatility better than historical measures. \\
\hline Taylor et al. (2010) & US & $1996-1999$ & $\begin{array}{l}\text { ATM implied volatility outperforms model-free implied volatility and historical measures in } \\
\text { forecasting future volatility for longer horizons. }\end{array}$ \\
\hline Bernales and Guidolin (2014) & US & $1996-2006$ & $\begin{array}{l}\text { Evidence of strongly predictive features of the implied volatility surface in the cross-section of } \\
\text { equity options. }\end{array}$ \\
\hline Bernales and Guidolin (2015) & US & $1996-2007$ & $\begin{array}{l}\text { Learning is a potential reason for the predictive features of the implied volatility surface, which is } \\
\text { suggested by a learning model that generates the forecasting characteristics of the implied } \\
\text { volatility surface observed empirically from equity options. }\end{array}$ \\
\hline
\end{tabular}


Table 7: Option-implied information about the probability of default

\begin{tabular}{|c|c|c|c|}
\hline & Market & Period & Main findings \\
\hline Benkert (2003) & International & $1999-2002$ & ATM implied volatility is a significant determinant of CDS spreads. \\
\hline Cao et al. (2006) & US & $1996-2004$ & $\begin{array}{l}\text { ATM implied volatility is a significant determinant of CDS spreads, especially for firms with lower } \\
\text { credit ratings, higher option trading volumes, and higher option open interest. }\end{array}$ \\
\hline Capuano (2008) & US & 2008 & The option-implied probability of default increases before credit events. \\
\hline Cremers et al. (2008) & US & $1996-2002$ & Implied volatility and implied skewness are related to credit spreads. \\
\hline Camara et al. (2012) & US & $1996-2008$ & The option-implied probability of default outperforms standard credit risk measures. \\
\hline Carr and Wu (2011) & US & $2005-2007$ & Option-implied probabilities of default closely match those extracted from CDS contracts. \\
\hline Kita (2012) & US & $2010-2011$ & Implied volatility and implied skewness are related to credit spreads. \\
\hline Wang et al. (2013) & US & $2001-2008$ & The volatility risk premium has explanatory power regarding credit spreads. \\
\hline Da Fonseca and Gottschalk (2014) & Europe & $2007-2012$ & ATM implied volatility is a significant determinant of CDS spreads. \\
\hline Taylor et al. (2014) & US & $2007-2009$ & $\begin{array}{l}\text { Assuming stock returns follow a mixed lognormal distribution results in more accurate implied } \\
\text { probabilities of default. }\end{array}$ \\
\hline Chang and Orosi (2016) & US & $2008-2009$ & Adjusting for positive expected recovery improves the accuracy of implied default probabilities. \\
\hline Vilsmeier (2016) & US & 2011 & The option-implied probability of default increases before credit events. \\
\hline Conrad et al. (2017) & US & $2001-2012$ & Option-implied probabilities of default closely match those extracted from CDS contracts. \\
\hline
\end{tabular}

